\title{
Preservation of bioactive compounds of a green vegetable smoothie using short time-high temperature mild thermal treatment
}

\author{
Noelia Castillejo ${ }^{1}$, Ginés Benito Martínez-Hernández ${ }^{1,2}$, \\ Kamila Monaco ${ }^{3}$, Perla A Gómez ${ }^{2}$, Encarna Aguayo ${ }^{1,2}$, \\ Francisco Artés ${ }^{1,2}$ and Francisco Artés-Hernández ${ }^{1,2}$
}

\begin{abstract}
Smoothies represent an excellent and convenient alternative to promote the daily consumption of fruit and vegetables in order to obtain their health-promoting benefits. Accordingly, a green fresh vegetables smoothie ( $77.2 \%$ cucumber, $12 \%$ broccoli and $6 \%$ spinach) rich in health-promoting compounds was developed. Soluble solids content, $\mathrm{pH}$ and titratable acidity of the smoothie were $4.3 \pm 0.4^{\circ} \mathrm{Bx}, 4.49 \pm 0.01$ and $0.22 \pm 0.02 \mathrm{mg}$ citric acid $100^{-1} \mathrm{~g} \mathrm{fw}$, respectively. Two thermal treatments to reduce microbial loads and preserve quality were assayed: $\mathrm{T} 1\left(3 \mathrm{~min}\right.$ at $\left.80^{\circ} \mathrm{C}\right)$ and $\mathrm{T} 2\left(45 \mathrm{~s}\right.$ at $\left.90^{\circ} \mathrm{C}\right)$. Fresh blended unheated samples were used as control (CTRL). The smoothie presented a viscoelastic behaviour. T1 and T2 treatments reduced initial microbial loads by 1.3-2.4 and 1.4-3.1 log units, respectively. Samples were stored in darkness at 5 and $15^{\circ} \mathrm{C}$. Colour and physicochemical changes were reduced in thermal-treated samples throughout storage, which were better preserved at $5^{\circ} \mathrm{C}$ rather than at $15^{\circ} \mathrm{C}$. Vitamin $\mathrm{C}$ changes during storage were fitted with a Weibullian distribution. Total vitamin $\mathrm{C}$ losses of $\mathrm{T} 1$ and $\mathrm{T} 2$ samples during storage at $15^{\circ} \mathrm{C}$ were greatly reduced when they were stored at $5^{\circ} \mathrm{C}$. Initial total phenolic content $\left(151.1 \pm 4.04 \mathrm{mg} \mathrm{kg}^{-1} \mathrm{fw}\right)$ was 44 and $36 \%$ increased after T1 and T2 treatments, respectively. The 3-p-coumaroyl quinic and chlorogenic acids accounted the 84.7 and $7.1 \%$ relative abundance, respectively. Total antioxidant capacity $\left(234.2 \pm 20.3 \mathrm{mg}\right.$ Trolox equivalent $\mathrm{kg}^{-1} \mathrm{fw}$ ) remained constant after the thermal treatments and was better maintained during storage in thermal-treated samples. Glucobrassicin accounted the $81 \%$ of the initial total glucosinolates content $\left(117.8 \pm 22.2 \mathrm{mg} \mathrm{kg}^{-1} \mathrm{fw}\right)$ of the smoothie. No glucosinolates losses were observed after T2 treatment being better preserved in thermaltreated samples. Conclusively, a short time-high temperature mild thermal treatment (T2) showed better quality and bioactive compounds retention in a green fresh vegetable smoothie during low temperature storage.
\end{abstract}

\section{Keywords}

Phenolic compounds, glucosinolates, vitamin C, antioxidants, quality, beverages

Date received: 29 March 2016; accepted: 31 March 2016

\section{INTRODUCTION}

Clinical and epidemiological research indicates that at least $80 \%$ of current chronic diseases and premature deaths are preventable with changes in diet and consumer lifestyle (Anand et al., 2008). Fruit and

Food Science and Technology International 23(1) 46-60

(C) The Author(s) 2016 Reprints and permissions:

sagepub.co.uk/journalsPermissions.nav

DOI: $10.1177 / 1082013216656240$

fst.sagepub.com

๑SAGE

\footnotetext{
${ }^{1}$ Postharvest and Refrigeration Group, Department of Food Engineering, Universidad Politécnica de Cartagena, Cartagena, Spain

${ }^{2}$ Institute of Plant Biotechnology, Universidad Politécnica de Cartagena, Cartagena, Spain

${ }^{3}$ Department of Chemistry and Biochemistry, São Paulo State University, Botucatu, Brazil

\section{Corresponding author:}

Francisco Artés-Hernández, Postharvest and Refrigeration Group, Department of Food Engineering, Universidad Politécnica de Cartagena, Paseo Alfonso XIII, 48, 30203 Cartagena, Murcia, Spain.

Email: fr.artes-hdez@upct.es
} 
vegetables have a high content of phytochemicals responsible of preventative effects on cardiovascular diseases, cancers, hypertension and other chronic conditions such as diabetes and obesity derived from their phytochemicals (Boeing et al., 2012). However, fruits and vegetables consumption consistently is below the $400 \mathrm{~g}$ of fruits and vegetables daily intake which has been worldwide promoted by several programmes such as '5 A Day' (WHO/FAO, 2003). Smoothies represent an excellent and convenient alternative to promote the daily consumption of fruit and vegetables. Smoothies are non-alcoholic beverages prepared from fresh or frozen fruit and/or vegetables, which are blended and usually mixed with crushed ice to be immediately consumed. Often, some smoothies may include other components like yogurt, milk, ice cream, lemonade or tea. They have a milk shake-like consistency that is thicker than slush drinks (Rodríguez-Verástegui et al., 2015). Recent research has shown that daily consumption of green smoothies may enhance health quality of consumers (Maeda, 2013). The main issue of the smoothie processing is the limited shelf-life of these products since they are susceptible to spoilage (Buzrul et al., 2008) and quality degradation. For that reason, mild thermal treatments must be used during processing in order to increase the shelf-life while keeping quality (Di Cagno et al., 2011). Furthermore, storage at low temperature up to $5^{\circ} \mathrm{C}$ is recommended. However, the treatment should not be much aggressive to preserve its nutritional and sensory quality. Thermal treatment (generally in the range of $80-95^{\circ} \mathrm{C}$ ) is applied for the inactivation of spoilage enzymes in smoothies, fruit purées and juices (Barba et al., 2012). However, thermal treatments may reduce the phytochemical content of smoothies, such as antioxidants among others, in detriment of related health-promoting properties. Studies about the effects of thermal processing and subsequent storage on bioactive compounds and quality changes of fresh vegetable smoothies are very scarce and no previous data for green smoothies are so far reported. For that reason, the aim of this work was to study the effect of two different mild conventional heat treatments on quality changes, as well as on selected bioactive compounds of a green fresh vegetable smoothie throughout storage at 5 and $15^{\circ} \mathrm{C}$.

\section{MATERIALS AND METHODS}

\section{Plant material and smoothie preparation}

Fresh vegetables, purchased at a local supermarket, were sanitised with $75 \mathrm{mgl}^{-1} \mathrm{NaClO}$ during 2 min and then rinsed with cold tap water for 1 min. Cucumbers were peeled and all vegetables were then cut and blended (MX2050 blender, Braun, Germany). The green smoothie composition was $77.2 \%$ cucumber,
$12 \%$ broccoli and $6 \%$ spinach. The nutritional composition of the smoothie was determined with the software DIAL 1.0 (Ortega-Anta et al., 2008) and it is presented as Supplementary Material 1. Citric acid $(4.8 \%)$ was added in order to decrease the $\mathrm{pH}$ below 4.5 and reduce microbial growth of the smoothie during subsequent storage.

\section{Thermal treatments and storage conditions}

Thermal treatments were applied by using a Mastia thermoresistometer described by Conesa et al. (2009). Immediately after blending, the sterilised vessel of the thermoresistometer was filled with $400 \mathrm{ml}$ of the smoothie. For treatment T1, the thermoresistometer was programmed to increase the initial smoothie temperature $\left(8 \pm 2{ }^{\circ} \mathrm{C}\right)$ with a heating rate of $30^{\circ} \mathrm{C} / \mathrm{min}$ to $80^{\circ} \mathrm{C}$, then maintained for $3 \mathrm{~min}$ and cooled down to a final temperature of $40^{\circ} \mathrm{C}$ (heating rate of $30^{\circ} \mathrm{C} / \mathrm{min}$ ). For treatment $\mathrm{T} 2$, the thermoresistometer was programmed to increase the initial smoothie temperature with a heating rate of $30^{\circ} \mathrm{C} / \mathrm{min}$ to $90^{\circ} \mathrm{C}$, then maintained for $45 \mathrm{~s}$ and cooled down to a final temperature of $40^{\circ} \mathrm{C}$ (heating rate of $30^{\circ} \mathrm{C} / \mathrm{min}$ ). After thermal treatments, the smoothie temperature was cooled down to $4{ }^{\circ} \mathrm{C}$ submerging the vessel in an ice water bath while continuously agitation was programmed in the thermoresistometer. Samples were stored in darkness at 5 and $15^{\circ} \mathrm{C}$ up to 49 days depending on storage temperature. Fresh blended unheated samples were used as control (CTRL). Five replicates per treatment and sampling day, for each storage temperature, were prepared.

\section{Rheological properties of smoothies}

Rheological measurements were executed using an ARG2 stress-controlled rheometer (TA Instruments, New Castle, DE, USA) equipped with serrated (to prevent wall depletion phenomena) plate-plate geometry $(20 \mathrm{~mm}$, gap $2 \mathrm{~mm})$ according to Castillejo et al. (2016). Briefly, oscillatory tests were performed within the linear viscoelastic region for the samples previously equilibrated $\left(25^{\circ} \mathrm{C}\right.$ for $\left.1 \mathrm{~min}\right)$ between the plates. Storage modulus $\left(\mathrm{G}^{\prime}\right)$ and loss modulus $\left(\mathrm{G}^{\prime \prime}\right)$ were determined in a frequency range of $100-0.2 \mathrm{~Hz}$. The strain value was obtained by preliminary strain sweep oscillatory trials to determine the linear viscoelastic region. The strain sweep oscillatory tests were carried out at a frequency of $1 \mathrm{~Hz}$ and in a range of shear strain of $0.01-10 \%$. Flow tests were also used to cover shear rate range between $10^{-2} / \mathrm{s}$ and $10^{2} / \mathrm{s}$. All experiments were carried out at $25^{\circ} \mathrm{C}$. Rheological data are presented as Supplementary Material 2. Three repetitions of the dynamic-mechanical experiments were performed for each smoothie sample. 


\section{Total dietary fibre (DF) and mineral content}

The contents of pectin, hemicellulose, cellulose, lignin and ash in the smoothies were studied by thermogravimetric analysis (TGA), conducted on a TGA/DSC HT thermogravimetric analyser (Mettler-Toledo $\mathrm{GmbH}$, Schwerzenbach, Switzerland) as previously described (Castillejo et al., 2016). Briefly, derivative thermogravimetric curves of approximately $10 \mathrm{mg}$ of sample powder (dried at $105^{\circ} \mathrm{C}$ for $24 \mathrm{~h}$ ) were analysed by derivative weight loss (see Supplementary Material 3). The temperature for the maximal weight loss $\left(\mathrm{T}_{\max }\right)$ at $90{ }^{\circ} \mathrm{C}$ is attributed to the free water loss. The decomposition peaks at the $\mathrm{T}_{\max }$ of 190,270 and $321^{\circ} \mathrm{C}$ are assigned to pectin, hemicelluloses and cellulose, respectively (Castillejo et al., 2016). The weight percentage of each component in the analysed samples was obtained as the mass loss produced during volatilisation.

The mineral content of the samples was analysed by $\mathrm{X}$-ray fluorescence (XRF) according to MartínezHernández et al. (2015). For the XRF analyses a spectrometer S4 Pioneer (Bruker Corporation, Billerica, MA, USA) was used, equipped with a $\mathrm{Rh}$ anticathode $\mathrm{X}$-ray tube (20-60 kV, 5-150 mA and $4 \mathrm{~kW}$ maximum), five analyser crystals (LiF200, LiF220, Ge, PET and XS-55), sealed proportional counter for light elements detection and a scintillation counter for heavy elements with slight modifications. The recorded spectrum was evaluated by the fundamental parameters method using the Spectra plus software EVA 1.7. Mineral content was expressed as $\mathrm{g} \mathrm{kg}^{-1}$ dry weight (dw) and $\mathrm{mg} \mathrm{kg}^{-1}$ $\mathrm{dw}$ for major minerals and trace elements, respectively. Each of the five replicates was analysed by duplicate.

\section{Informal sensory evaluation}

An informal sensory evaluation was conducted by an untrained panel of eight assessors to address if differences in visual appearance, flavour, texture, off-colours, off-odours, lumpiness, turbidity, precipitation/phase separation and overall quality were noticeable among the three sample types. Accordingly, shelf-life of the samples was established based on overall quality scores.

\section{Microbial analysis}

Mesophilic, psychrophilic, Enterobacteriaceae, and yeast and mould growth were determined using standard enumeration methods according to Castillejo et al. (2016). All microbial counts were reported as log colony forming units per gram of product $\left(\log \mathrm{CFU} \mathrm{g}^{-1}\right)$. Each of the five replicates was analysed by duplicate. The presence of Salmonella spp., Listeria monocytogenes and generic Escherichia coli was monitored according to the European legislation (Regulation EC 1441/2007, 2007).

\section{Physiochemical analyses}

The $\mathrm{pH}$, titratable acidity (TA) and total soluble solids content (SSC) of smoothies were determined according to Castillejo et al. (2016). Briefly, a pH meter was used to analyse the $\mathrm{pH}$. The SSC of the smoothies was determined by a digital hand-held refractometer (Atago N1, Tokyo, Japan) at $25^{\circ} \mathrm{C}$ and expressed as ${ }^{\circ} \mathrm{Bx}$. TA was determined by the titration of $5 \mathrm{ml}$ of juice plus $45 \mathrm{ml}$ of distilled water with $0.1 \mathrm{~mol}^{-1} \mathrm{NaOH}$ to $\mathrm{pH} 8.1$ (T50, Metter Toledo, Milan, Italy) and expressed as g citric acid $100 \mathrm{ml}^{-1}$. Three replicates per treatment were analysed.

Colour was determined using a colorimeter (Minolta CR-300 Series, Japan) calibrated with a white reference plate (light source $\mathrm{C}$ ), $2^{\circ}$ observer and $8 \mathrm{~mm}$ viewing aperture. Samples were introduced in a special glass tube mounted on a device connected to the colorimeter. Measurements were recorded using the standard tristimulus parameters ( $\mathrm{L}^{*}, \mathrm{a}^{*}, \mathrm{~b}^{*}$ ) of the CIE Lab system on three equidistant points of each replicate. Three colour readings were taken turning the tube at every read and all three measurements were automatically averaged by the device and recorded. Total colour differences $(\Delta E)$ throughout storage compared to their respective initial values were calculated according to equations previously described (Walkling-Ribeiro et al., 2010).

\section{Chlorophylls content}

Chlorophyll content was determined according to Martínez-Hernández et al. (2011). Briefly, $0.5 \mathrm{~g}$ ground frozen $\left(-80^{\circ} \mathrm{C}\right)$ sample was mixed with $9 \mathrm{ml}$ of hexane and $15 \mathrm{ml}$ of a mixture of methanol/acetone $(1: 2, \mathrm{v} / \mathrm{v})$. The extraction was carried out for $4 \mathrm{~h}$ (darkness in ice bed shaken continuously at $200 \times \mathrm{G}$ ). After extraction, $25 \mathrm{ml}$ of a solution $1 \mathrm{M} \mathrm{NaCl}$ was added, samples were shaken again in a vortex (Heidolph, Reax Control, Kelheim, Germany) and the upper of the three layers formed was used as chlorophyll extract. An aliquot of $1 \mathrm{ml}$ was placed into a quartz cuvette (Hellma GmbH \& Co., Müllheim, Germany) and the absorbance (A) at 662 and $644 \mathrm{~nm}$ was measured using a UV-visible spectrophotometer (Hewlet Packard, model 8453, Columbia, USA). The equation $\mathrm{Ch}=[10.05 \times \mathrm{A} 662-0.766 \times \mathrm{A} 644]+[16.37 \times \mathrm{A} 644-$ $3.14 \times$ A662] developed by Wellburn (1994) was used to determine the total chlorophyll content $(\mathrm{Ch})$ which was expressed as $\mathrm{mg} \mathrm{kg}^{-1} \mathrm{fw}$. Each of the three replicates was analysed by triplicate.

\section{Bioactive compounds}

Vitamin C. The ascorbic (AA) and dehydroascorbic (DHA) acids were measured based on the method of Zapata and Dufour (1992) with instruments and 
methodology described by Martínez-Hernández et al. (2013). Briefly, $5 \mathrm{~g}$ ground frozen $\left(-80^{\circ} \mathrm{C}\right)$ sample was placed into a $25 \mathrm{ml}$ Falcon tube and $10 \mathrm{ml}$ of cold $\left(4^{\circ} \mathrm{C}\right)$ buffer $(0.1 \mathrm{M}$ citric acid, $0.05 \%$ EDTA, $4 \mathrm{mM}$ sodium fluoride and $5 \% \mathrm{MeOH}$ ) were added. The mixture was homogenised (Ultraturrax T25 basic, IKA, Berlin, Germany) for $10 \mathrm{~s}$, filtered (four-layer cheesecloth) and $\mathrm{pH}$ adjusted $(6 \mathrm{~N} \mathrm{NaOH})$ to 2.35-2.4. Subsequently, $750 \mu \mathrm{l}$ filtered $(0.45 \mu \mathrm{m}$ polyether sulphone filter) purified extract (Sep-Pak cartridges C18, Waters, Dublin, Ireland) was derivatised with $250 \mu$ of $7.7 \mathrm{M}$ 1,2-phenylenediamine for $37 \mathrm{~min}$ in darkness at room temperature. Immediately after derivatisation, $20 \mu 1$ were injected on a Gemini NX $(250 \mathrm{~mm} \times 4.6 \mathrm{~mm}$, $5 \mu \mathrm{m}) \mathrm{C} 18$ column (Phenomenex, Torrance CA, USA), using an HPLC (Series 1100 Agilent Technologies, Waldbronn, Germany) equipped with a G1322A degasser, G1311A quaternary pump, G1313A autosampler, G1316A column heater and G1315B photodiode array detector. AA and DHA were quantified using commercial standards (Sigma, St Louis, MO, USA). Calibration curves were made with at least six data points for each standard. Total vitamin $\mathrm{C}$ was calculated as the sum of AA and DHA and expressed as mg $\mathrm{kg}^{-1} \mathrm{fw}$. Each of the five replicates was analysed by triplicate.

Simultaneous analysis of phenolic compounds and intact glucosinolates. A smoothie sample of $9 \mathrm{~g}$ was homogenised (Ultra-turrax T-25, Ika-Labortechnik, Staufen, Germany) in $7 \mathrm{ml} 70 \% \mathrm{MeOH}$ under an ice water bath to avoid enzymatic activations. Immediately, samples were heated at $70^{\circ} \mathrm{C}$ for $15 \mathrm{~min}$ in a water bath under continuous agitation to inactivate myrosinase. Then, the samples were centrifuged $\left(13,000 \times \mathrm{g}, 10 \mathrm{~min}, 4^{\circ} \mathrm{C}\right)$. The supernatants were collected, filtered through $0.20 \mu \mathrm{m}$ syringe PTFE filters and used as intact glucosinolates/phenolic extracts.

Analysis and identification of phenolic and intact glucosinolates were conducted according to Fernández-León et al. (2013). An ultra high-performance liquid chromatography instrument (Shimadzu, Kyoto, Japan) equipped with a DGU-20A degasser, LC-30AD quaternary pump, SIL-30AC autosampler, CTO-10AS column heater and SPDM-20A photodiode array detector was used. Chromatographic analyses were carried out onto a Kinetex C18 column $(100 \mathrm{~mm} \times 4.6 \mathrm{~mm}, 2.6 \mu \mathrm{m}$ particle size; Phenomenex, Macclesfield, UK). Phenolic acids were quantified as equivalents of chlorogenic acid (5-caffeoylquinic acid; Sigma, St Louis, MO, USA) and sinapic acid (Sigma, St Louis, MO, USA). Glucosinolates were quantified as sinigrin equivalents. The results were expressed as $\mathrm{mg} \mathrm{kg}^{-1} \mathrm{fw}$. Each of the five replicates was analysed by duplicate.
LC/UV-PAD/ESI-MSn analyses were carried out in an Agilent HPLC 1100 series equipped with a photodiode array detector and mass detector in series (Agilent Technologies, Waldbronn, Germany).

Total antioxidant capacity (TAC). TAC extraction and analysis were conducted using the same instruments and methodology described by Rodríguez-Verástegui et al. (2015) using three different methods: free radical scavenging capacity with 2,2-diphenyl-1-picrylhydrazil (DPPH) (Brand-Williams et al., 1995), ferric reducing antioxidant power (FRAP) (Benzie and Strain, 1999) and 2,2'-azino-bis (3-ethylbenzothiazoline-6-sulphonic acid) (ABTS) (Cano et al., 1998). All TAC data were expressed as $\mathrm{mg}$ of Trolox equivalents $\mathrm{kg}^{-1} \mathrm{fw}$. Each of the five replicates was analysed by duplicate.

\section{Statistical analysis}

The experiment was a two-factor (treatment $\times$ storage time) design subjected to analysis of variance (ANOVA) using Statgraphics Plus software (vs. 5.1, Statpoint Technologies Inc., Warrenton, USA). Statistical significance was assessed at the level $P=0.05$, and Tukey's multiple range test was used to separate means.

\section{RESULTS AND DISCUSSION}

\section{Rheological properties}

The texture of a smoothie has to provide a balance between desired mechanical stability (for storage and handling) and desired instability (to elicit a specific texture attribute during mastication). The rheological properties of the smoothie are presented as Supplementary Material 2. $\mathrm{G}^{\prime}$ of smoothies was greater than $G^{\prime \prime}$ at any given point in the frequency sweep tests (see Supplementary Material 2). This fact indicates a dominant contribution of the elastic component to the viscoelasticity of the smoothie, behaviour typical for a viscoelastic solid. This means that the attractive forces become dominant due to the strong hydrogen bond and hydrophobic association (Basu et al., 2011). The $\tan \delta$ value (ratio between loss and storage modulus, also known as loss tangent) is a direct measure of the relative importance of viscous and elastic effects in the sample. The $\tan \delta$ of samples was lower than 1 thus indicating a gel-like behaviour. Apparent viscosity of the green smoothie was not greatly changed after thermal treatment as observed in Supplementary Material 2. The effective shear rate range in the mouth is 40 $50 \mathrm{~s}^{-1}$, which would have implied actual sensory consistency (Wood and Goff, 1973). The viscosity of T1 samples was slightly higher than T2 samples within the shear rate range $40-50 \mathrm{~s}^{-1}$. 


\section{Total DF and mineral content}

The total DF content of the smoothie was $4.4 \pm 0.2 \%$ wet basis (wb) (data not shown). Pectin and hemicellulose contents of the smoothie were $0.8 \pm 0.1$ and $1.9 \pm 0.3 \%$ $\mathrm{wb}$, respectively. The smoothie accounted $1.8 \pm 0.3 \% \mathrm{wb}$ of cellulose (data not shown). According to The Code of Federal Regulations (FDA, 2015), food products which contain $20 \%$ or more of the recommended daily nutrient intakes (RNIs) for fibre $\left(25 \mathrm{~g} \mathrm{day}^{-1}\right)$ are considered as an 'excellent source of fibre'. Accordingly, this green smoothie can be considered as an 'excellent source of fibre' since a portion of $250 \mathrm{~g}$ provides approximately $50 \%$ of the RNIs for fibre.

The P, S, Na, K, Ca, Mg, Cl, Al and Si contents of the smoothie were $0.75 \pm 0.01,0.48 \pm 0.00,0.47 \pm 0.01$, $4.24 \pm 0.00, \quad 0.41 \pm 0.00, \quad 0.30 \pm 0.00, \quad 0.48 \pm 0.00$, $0.01 \pm 0.00$ and $0.04 \pm 0.00 \mathrm{~g} \mathrm{~kg}^{-1} \mathrm{fw}$, respectively (data not shown). The Fe, Mn and $\mathrm{Zn}$ contents of the smoothie were $8.72 \pm 0.27, \quad 3.11 \pm 0.24$ and $5.93 \pm 0.13 \mathrm{mg} \mathrm{kg}^{-1} \mathrm{fw}$, respectively (data not shown). A $250 \mathrm{~g}$ portion of this smoothie provides 29-34, 9-15, 7-12 and $15-21 \%$ of the RNIs for $\mathrm{Mg}, \mathrm{Ca}, \mathrm{Fe}$ and $\mathrm{Zn}$, respectively, covering population groups with special nutritional requirements such as elders, pregnant women or adolescents (FAO/WHO, 2004).

\section{Informal sensory evaluation}

Visual appearance, flavour, texture, off-colours, offodours, lumpiness, turbidity, precipitation/phase separation and overall quality of CTRL smoothie were reported to be over the limit of acceptability up to 21 days at $5{ }^{\circ} \mathrm{C}$ by an informal sensory panel test of eight assessors (data not shown). Thermally treated smoothies maintained their sensory acceptance up to 49 days at $5^{\circ} \mathrm{C}$. Inappropriate storage at $15^{\circ} \mathrm{C}$ reduced sensory acceptance to seven days. Accordingly, the shelf-lives of the smoothies were established based on those sensory analyses.

\section{Microbial analysis}

The mesophilic load of CTRL smoothie on processing day was $4.4 \pm 0.2 \log$ CFU g ${ }^{-1}$ (Figure 1(a)). Thermal treatments reduced mesophilic load by $1.7-1.8 \log$ units without differences among them. Zhao et al. (2014) reported $2 \log$ units mesophilic reductions in cucumber juice heat treated at $85^{\circ} \mathrm{C}$ for $15 \mathrm{~s}$. The similar microbial reduction in the juice with shorter treatment time may be owed to the fibres and other particles contained in the smoothie which may difficult the heat transmission contrary to the juice. Great mesophilic increases of 4.7 and $5.2 \mathrm{log}$ units were observed in CTRL and thermaltreated smoothies after seven days at $15^{\circ} \mathrm{C}$, respectively.
However, storage at $5^{\circ} \mathrm{C}$ greatly reduced mesophilic growth of CTRL and heat-treated samples compared to those stored at $15^{\circ} \mathrm{C}$ since increments of 3.6-3.8 and $0.7 \log$ units were registered after 21 days at $5^{\circ} \mathrm{C}$. Heat-treated samples stored at $5^{\circ} \mathrm{C}$ showed a great mesophilic growth (2.9-3.1 log units) in the first 11 days remaining those loads almost unchanged $(<0.4 \log$ units changes) until day 35 . However, those microbial loads of $\mathrm{T} 1$ and $\mathrm{T} 2$ samples were increased by 1.4 and $1.9 \log$ units, respectively, from day 39 to day 49. The higher mesophilic growth of heat-treated samples could be explained by different hypotheses: (1) the vegetative or spore cells which resisted to the thermal treatment, due to their higher thermal resistance and/or the protecting effects of the smoothie matrix, could grow better due to the lower microbial competence for the nutrients. (2) The used heat treatment completely inactivated the initial myrosinase activity (163.0 nmole sinigrin transformed per $\mathrm{g}$ fw of sample; data not shown), which is responsible for the glucosinolates conversion to isothiocyanates. Isothiocyanates from broccoli have shown high antimicrobial activities contrary to glucosinolates (Vig et al., 2009). Accordingly, the glucosinolate-isothiocyanate conversion was possible in untreated unheated samples, contrary to heat-treated samples, with the observed preserving benefits from the isothiocyanates throughout storage of smoothies. Therefore, our previous preliminary non-published data showed that mesophilic increase of $2 \log$ units in untreated smoothie after 28 days at $5^{\circ} \mathrm{C}$ was doubled when that untreated smoothie was prepared without broccoli (data not shown).

Initial psychrophilic count of CTRL smoothie was $5.1 \pm 0.3 \log \mathrm{CFU} \mathrm{g}^{-1}$ (Figure 1(b)). Psychrophilic counts were reduced by 2.4 and $3.1 \log$ units after T1 and $\mathrm{T} 2$ treatments, respectively. During storage at $15^{\circ} \mathrm{C}$, psychrophilic counts of CTRL, T1 and T2 samples augmented by 3.1, 2.8 and $3.5 \log$ units after seven days, respectively. However, and similarly to mesophilic data, although heat-treated samples showed great increases of 2.6-3.0 log units after 11 days at $5^{\circ} \mathrm{C}$ loads changes were lower than $2.4 \mathrm{log}$ units in the last 38 days of storage. In contrast, CTRL samples did not significantly change after 21 days at $5^{\circ} \mathrm{C}$. CTRL and heat-treated samples registered psychrophilic counts of $5.5 \pm 0.4$ and $6.7 \pm 0.8-7.0 \pm 0.1 \log \mathrm{CFU} \mathrm{g}^{-1}$ after 21 and 49 days at $5{ }^{\circ} \mathrm{C}$, respectively.

Initial Enterobacteriaceae counts of $3.8 \pm 0.4 \mathrm{log}$ $\mathrm{CFU} \mathrm{g}^{-1}$ were only significantly reduced after $\mathrm{T} 2$ treatment by $1.6 \quad \log$ units (Figure 1(c)). The Enterobacteriaceae levels of CTRL and T1 samples stored at $15{ }^{\circ} \mathrm{C}$ increased by $2.2-2.3$ after seven days while $\mathrm{T} 2$ samples increased in a greater extent with $3.5 \log$ units increments after seven days. CTRL and thermal-treated samples registered Enterobacteriaceae 


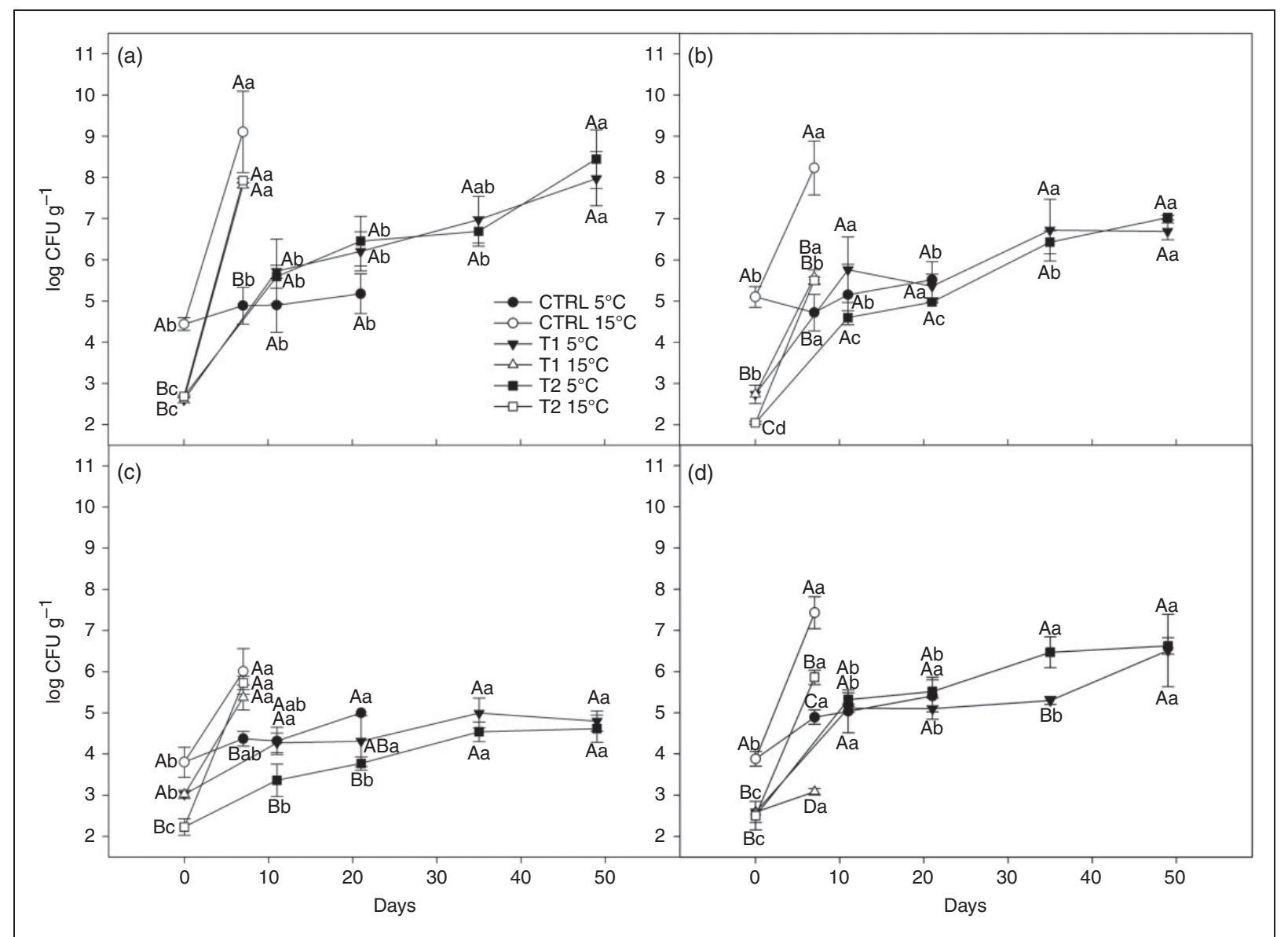

Figure 1. Mesophilic (a), psychrophilic (b), Enterobacteriaceae (c) and yeast and moulds (d) counts (log CFU g ${ }^{-1}$ ) of untreated (CTRL) and heat-treated (T1 and T2) green vegetables smoothies stored at 5 and $15^{\circ} \mathrm{C}(n=5 \pm S D)$.

counts of $5.0 \pm 0.4$ and $4.6 \pm 0.3-4.8 \pm 0.3 \log \mathrm{CFU}$ $\mathrm{g}^{-1}$ after 21 and 49 days of at $5^{\circ} \mathrm{C}$, respectively.

Yeasts and moulds counts of CTRL smoothie of $3.9 \pm 0.2 \log$ CFU g ${ }^{-1}$ were reduced by $1.3-1.4 \log$ units after heat treatments without significant differences among them (Figure 1(d)). Similar to mesophiles, dynamic heating system during a milder heat treatment $\left(70{ }^{\circ} \mathrm{C}\right.$ for $\left.15 \mathrm{~s}\right)$ induced greater yeasts and moulds reductions (3.7 log units) in a fruit smoothie (Walkling-Ribero et al., 2010). Furthermore, data from Zhao et al. (2014) showed better heat transmission in cucumber juice compared to our smoothie since initial yeasts and moulds $\left(4 \log \mathrm{CFU} \mathrm{g^{-1 }}\right.$ ) were greatly reduced below the detection limit $\left(1 \log \mathrm{CFU} \mathrm{g^{-1 }}\right)$. Yeasts and moulds counts of CTRL and T2 samples were incremented by 3.6 and $3.4 \log$ units, respectively, after seven days at $15^{\circ} \mathrm{C}$ while $\mathrm{T} 1$ samples only increased in $0.5 \mathrm{log}$ units. Similar to mesophilic and psychrophilic, yeasts and moulds counts greatly augmented by 2.5 and $2.8 \log$ units after 11 days followed by a $1.3-1.4 \log$ units increment in the last 38 days of storage at $5^{\circ} \mathrm{C}$. CTRL and thermal-treated samples showed final yeasts and moulds counts of $5.4 \pm 0.4$ and $6.5 \pm 0.9-6.6 \pm 0.2 \log \mathrm{CFU} \mathrm{g}{ }^{-1}$ after 21 and 49 days at $5{ }^{\circ} \mathrm{C}$, respectively.

Conclusively, thermal treatments, with better initial microbial reductions achieved by $\mathrm{T} 2$, combined with low temperature storage, kept microbial loads below $6 \log$ units after 39 days at $5{ }^{\circ} \mathrm{C}$. Although CTRL samples showed a similar microbial behaviour to heat-treated samples during low temperature storage, thermal treatment is needed to inactivate qualitydegradation enzymes, as recently reported in vegetable smoothies (Rodríguez-Verástegui et al., 2015), in order to reduce colour changes of smoothies during storage as shown later.

\section{SSC, pH and TA}

CTRL smoothie showed an initial SSC of $4.3 \pm 0.4^{\circ} \mathrm{Bx}$ (Table 1). Di Cagno et al. (2011) reported a higher SSC of $10.8^{\circ} \mathrm{Bx}$ in a green smoothie due to the high fruit content (40\% kiwifruits, $7 \%$ fennels, $8 \%$ spinach and $15 \%$ papaya). Thermal treatment did not induce SSC 
Table 1. Soluble solids content (SSC), pH, titratable acidity (TA), total colour differences ( $\triangle \mathrm{E})$ and total chlorophylls content of untreated (CTRL) and heat-treated (T1 and T2) green vegetables smoothies stored at 5 and $15^{\circ} \mathrm{C}(\mathrm{n}=5 \pm$ SD)

\begin{tabular}{|c|c|c|c|c|c|c|c|}
\hline Treatment & $\mathrm{T}^{\mathrm{a}}\left({ }^{\circ} \mathrm{C}\right)$ & Day & SSC ( $\left.{ }^{\circ} \mathrm{Bx}\right)$ & $\mathrm{pH}$ & $\begin{array}{l}\text { TA (g citric acid } \\
100 \mathrm{ml}^{-1} \text { ) }\end{array}$ & $\Delta \mathrm{E}$ & $\begin{array}{l}\text { Total chlorophylls } \\
\left(\mathrm{mg} \mathrm{kg}^{-1} \mathrm{fw}\right)\end{array}$ \\
\hline CTRL & - & 0 & $4.30 \pm 0.35 \mathrm{Aa}$ & $4.49 \pm 0.0 \mathrm{IAb}$ & $0.22 \pm 0.02 \mathrm{Ab}$ & - & $58.9 \pm 1.7 \mathrm{Aa}$ \\
\hline T1 & - & 0 & $4.17 \pm 0.15 \mathrm{Aa}$ & $4.36 \pm 0.03 \mathrm{Cb}$ & $0.24 \pm 0.01 \mathrm{Ac}$ & $5.02 \pm 0.02 \mathrm{Ab}$ & $19.0 \pm 0.5 \mathrm{Bb}$ \\
\hline T2 & - & 0 & $4.17 \pm 0.12 \mathrm{Aa}$ & $4.42 \pm 0.03 \mathrm{Ba}$ & $0.26 \pm 0.00 \mathrm{Ab}$ & $4.97 \pm 0.09 \mathrm{Ab}$ & $21.2 \pm 3.4 \mathrm{Ba}$ \\
\hline \multirow[t]{4}{*}{ CTRL } & 15 & 7 & $4.23 \pm 0.13 \mathrm{Ba}$ & $4.33 \pm 0.09 \mathrm{BCb}$ & $0.35 \pm 0.01 \mathrm{Ba}$ & $10.16 \pm 0.38--$ & $43.7 \pm 0.8 \mathrm{Ab}$ \\
\hline & 5 & 7 & $4.97 \pm 0.12 \mathrm{Aa}$ & $4.59 \pm 0.06 \mathrm{Aab}$ & $0.30 \pm 0.01 \mathrm{Ba}$ & $7.07 \pm 1.29-b$ & $45.4 \pm 1.1 \mathrm{Ab}$ \\
\hline & 5 & 11 & $4.40 \pm 0.36 \mathrm{Aa}$ & $4.48 \pm 0.05 \mathrm{Ab}$ & $0.27 \pm 0.01 \mathrm{Aab}$ & $8.63 \pm 0.22-a b$ & $45.4 \pm 1.9 \mathrm{Ab}$ \\
\hline & 5 & 21 & $4.57 \pm 0.15 \mathrm{Aa}$ & $4.62 \pm 0.03 \mathrm{Aa}$ & $0.29 \pm 0.03 \mathrm{Aa}$ & $10.73 \pm 0.69-a$ & $27.8 \pm 4.9 A c$ \\
\hline \multirow[t]{5}{*}{$\mathrm{T} 1$} & 15 & 7 & $4.17 \pm 0.15 \mathrm{Ba}$ & $4.23 \pm 0.04 \mathrm{Cb}$ & $0.66 \pm 0.07 \mathrm{Aa}$ & $6.47 \pm 0.35-\mathrm{a}$ & $17.2 \pm 0.7 \mathrm{Bc}$ \\
\hline & 5 & 11 & $4.17 \pm 0.12 \mathrm{Aa}$ & $4.49 \pm 0.01 \mathrm{Aab}$ & $0.23 \pm 0.02 \mathrm{Ac}$ & $6.00 \pm 0.19-b$ & $20.8 \pm 1.3 \mathrm{Bab}$ \\
\hline & 5 & 21 & $4.30 \pm 0.00 \mathrm{Ba}$ & $4.59 \pm 0,02 \mathrm{ABa}$ & $0.26 \pm 0.02 A c$ & $7.50 \pm 0.37-\mathrm{a}$ & $26.7 \pm 3.8 \mathrm{Aa}$ \\
\hline & 5 & 35 & $4.27 \pm 0.12 \mathrm{Aa}$ & $4.47 \pm 0.09 \mathrm{Aab}$ & $0.33 \pm 0.03 \mathrm{Ab}$ & $7.55 \pm 0.93-a$ & $11.5 \pm 3.2 \mathrm{Bc}$ \\
\hline & 5 & 49 & $3.27 \pm 0.3 \mathrm{IAb}$ & $4.45 \pm 0,09 \mathrm{Aab}$ & $0.62 \pm 0.03 \mathrm{Aa}$ & $7.66 \pm 0.22-a$ & $15.5 \pm 2.7 \mathrm{Abc}$ \\
\hline \multirow[t]{5}{*}{ T2 } & 15 & 7 & $4.23 \pm 0.15 \mathrm{Ba}$ & $4,49 \pm 0,10 A B a$ & $0.33 \pm 0.03 \mathrm{Bb}$ & $6.20 \pm 0.17-a$ & $19.7 \pm 1.5 \mathrm{Ba}$ \\
\hline & 5 & 11 & $4.17 \pm 0.42 \mathrm{Aa}$ & $4,47 \pm 0,02 \mathrm{Aa}$ & $0.25 \pm 0.02 \mathrm{Ab}$ & $7.11 \pm 0.57-a$ & $24.8 \pm 1.8 \mathrm{Ba}$ \\
\hline & 5 & 21 & $4.30 \pm 0.00 \mathrm{Ba}$ & $4,49 \pm 0,07 \mathrm{Ba}$ & $0.29 \pm 0.04 \mathrm{Ab}$ & .. & $16.2 \pm 2.5 \mathrm{Ba}$ \\
\hline & 5 & 35 & $4.27 \pm 0.25 \mathrm{Aa}$ & $4,44 \pm 0,05 \mathrm{Aa}$ & $0.36 \pm 0.13 \mathrm{Aab}$ & $7.90 \pm 0.70-a$ & $19.1 \pm 2.4 \mathrm{Aa}$ \\
\hline & 5 & 49 & $3.50 \pm 0.20 \mathrm{Ab}$ & $4,47 \pm 0,15 \mathrm{Aa}$ & $0.47 \pm 0.05 \mathrm{Ba}$ & $7.46 \pm 0.84-a$ & $22.3 \pm 7.8 \mathrm{Aa}$ \\
\hline
\end{tabular}

Different capital letters denote significant differences $(P \leq 0.05)$ among treatments stored at the same temperature for the same sampling day. Different lowercase letters denote significant differences $(P \leq 0.05)$ among sampling days for the same treatment stored at the same temperature.

changes. SSC of all smoothies remained quite constant after seven days of storage at $15^{\circ} \mathrm{C}$. Contrary, CTRL smoothie showed a SSC increase of $0.7^{\circ} \mathrm{Bx}$ after seven days at $5{ }^{\circ} \mathrm{C}$ followed by a decrease. Accordingly, CTRL smoothie registered $4.6 \pm 0.2^{\circ} \mathrm{Bx}$ after 21 days at $5^{\circ} \mathrm{C}$ with no differences regarding its respective initial level. SSC levels of T1 and T2 smoothies remained stable up to 35 days of storage at $5{ }^{\circ} \mathrm{C}$ followed by a decrease of 0.9 and $0.7^{\circ} \mathrm{Bx}$, respectively, from day 35 to day 49. The observed SSC decreases during storage may be owed to the sugars and other soluble solids used by microorganisms and enzymatic systems as substrates in several metabolic reactions.

The initial $\mathrm{pH}$ and TA of CTRL smoothie were $4.49 \pm 0.01$ and $0.22 \pm 0.02 \mathrm{mg}$ citric acid $100^{-1} \mathrm{~g} \mathrm{fw}$, respectively (Table 1). Data from Di Cagno et al. (2011) showed a higher TA of $0.6 \mathrm{mg}$ citric acid $100^{-1}$ $\mathrm{g}$ fw in a green smoothie owed to the high kiwifruit content $(40 \%)$ showing this fruit a high TA. Similar to $\mathrm{SSC}, \mathrm{pH}$ and TA did not register significant differences after thermal treatments. The $\mathrm{pH}$ of CTRL and T1 samples was slightly reduced by 0.2 and $0.4 \mathrm{pH}$ units, respectively, after seven days at $15^{\circ} \mathrm{C}$ although $\mathrm{pH}$ of $\mathrm{T} 2$ samples remained stable. Correspondingly, TA of CTRL and T1 samples increased 0.1 and $0.4 \mathrm{mg}$ citric acid $100^{-1} \mathrm{~g}$ fw, respectively, after seven days at $15{ }^{\circ} \mathrm{C}$ while $\mathrm{T} 2$ did not register differences during this period. No great $\mathrm{pH}$ and TA changes in CTRL samples were observed after 21 days at $5^{\circ} \mathrm{C}$. The $\mathrm{pH}$ of thermal-treated samples was constant throughout storage at both storage temperatures. Similarly, no $\mathrm{pH}$ changes were observed in untreated and heat treated $\left(100^{\circ} \mathrm{C}\right.$ for $\left.60 \mathrm{~s}\right)$ spinach puree after 43 days at $4{ }^{\circ} \mathrm{C}$ (Wang et al., 2013). Correspondingly, TA values of $\mathrm{T} 1$ and $\mathrm{T} 2$ did not change for 35 days at $5{ }^{\circ} \mathrm{C}$ followed by an increase from day 35 to day 49 registering values 0.38 and $0.20 \mathrm{mg}$ citric acid $100^{-1} \mathrm{~g} \mathrm{fw}$ higher, respectively, compared to their respective initial levels. As previously observed, microbial growth may be greatly reduced by thermal treatment and subsequent low temperature storage. Microorganisms consume sugars and other soluble solids during growth producing metabolic acidic products. Accordingly, SSC and $\mathrm{pH}$ decreased, and TA increased during storage of the smoothie being these changes greatly reduced in thermal-treated samples and during cold storage.

\section{Colour differences and total chlorophylls and carotenoids contents}

Colour is one of the most important quality parameters of smoothies to evaluate its storage quality. Green colour of vegetables is mainly due to chlorophylls which may be degraded due to certain degrading 
enzymes (chlorophyllase, $\mathrm{Mg}$-dechelatase and peroxidase). The initial $\mathrm{L}^{*}, \mathrm{a}^{*}$ and $\mathrm{b}^{*}$ values of CTRL smoothie were $41.9 \pm 1.9,-14.0 \pm 0.7$ and $22.7 \pm 0.1$, respectively (data not shown). The initial total chlorophylls content of CTRL smoothie was $58.9 \pm 1.7 \mathrm{mg}$ $\mathrm{kg}^{-1}$ fw (Table 1) accounting chlorophyll a $82 \%$ of total content (data not shown). Meng et al. (2014) found approximately $75 \mathrm{mg} \mathrm{kg}^{-1}$ fw total chlorophylls content in fresh-cut cucumber. The higher total chlorophylls content of our smoothie may be owed to the spinach contribution which has high chlorophylls content. Total chlorophyll content decreased by $64-68 \%$ after heat treatments without differences among them (Table 1). Accordingly, an initial $\Delta E$ of $4.97 \pm 0.09$ $5.02 \pm 0.02$ was observed after thermal treatments without significant differences among them (Table 1). However, milder thermal treatment $\left(72^{\circ} \mathrm{C}\right.$ for $\left.15 \mathrm{~s}\right)$ reported lower $\Delta E$ value (1.2) in fruit smoothie (Walkling-Ribeiro et al., 2010). Accordingly, a* value, the most important index evaluating instrumental colour in green vegetables, was increased from -11.2 to -6.5 in spinach puree after heat treatment at $100^{\circ} \mathrm{C}$ for $60 \mathrm{~s}$ (Wang et al., 2013).

Storage of CTRL samples either at 15 or $5^{\circ} \mathrm{C}$ induced total chlorophyll losses of approximately 26 and $53 \%$ after seven and 21 days at $5{ }^{\circ} \mathrm{C}$, respectively (Table 1). Although $\mathrm{T} 1$ and $\mathrm{T} 2$ samples stored at $5{ }^{\circ} \mathrm{C}$ showed higher total chlorophylls degradation trends
(67-71\%), these differences were not significant after seven days at $5{ }^{\circ} \mathrm{C}$ regarding CTRL samples. In general, thermally treated samples did not show total chlorophylls changes during storage at $5^{\circ} \mathrm{C}$ registering similar levels after 49 days compared to their respective initial levels. Accordingly, thermal treatments reduced colour changes during storage since CTRL smoothie registered $\Delta E$ of $10.16 \pm 0.38$ and $10.73 \pm 0.69$ after seven days at $15^{\circ} \mathrm{C}$ and 21 days at $5^{\circ} \mathrm{C}$, respectively, while $\mathrm{T} 1 / \mathrm{T} 2$ registered $\Delta E$ values of $6.47 \pm 0.35-6.20 \pm 0.17 /$ $7.66 \pm 0.22-7.46 \pm 0.84$ after 49 days at $5^{\circ} \mathrm{C}$. Similarly, spinach puree heat treated at $100^{\circ} \mathrm{C}$ for $60 \mathrm{~s}$ only showed $\mathrm{a}^{*}$ changes of 2.3 while untreated spinach puree reported $a^{*}$ changes of 6.5 after 43 days at $4{ }^{\circ} \mathrm{C}$ (Wang et al., 2013).

As observed, these heat treatments can reduce colour changes related to chlorophylls levels in the green smoothie due to inactivation of colour-degrading enzymes. Accordingly, great to nearly complete inactivations have been reported in broccoli and spinach puree after similar thermal treatments (Wang et al., 2012, 2013).

\section{Total vitamin C}

The initial total vitamin $\mathrm{C}$ (ascorbic acid + DHA) of CTRL smoothie was $731.5 \pm 53.3 \mathrm{mg} \mathrm{kg}^{-1} \mathrm{fw}$ (Figure 2). Ascorbic acid is easily oxidised by the enzymes ascorbate oxidase and ascorbic acid peroxidase

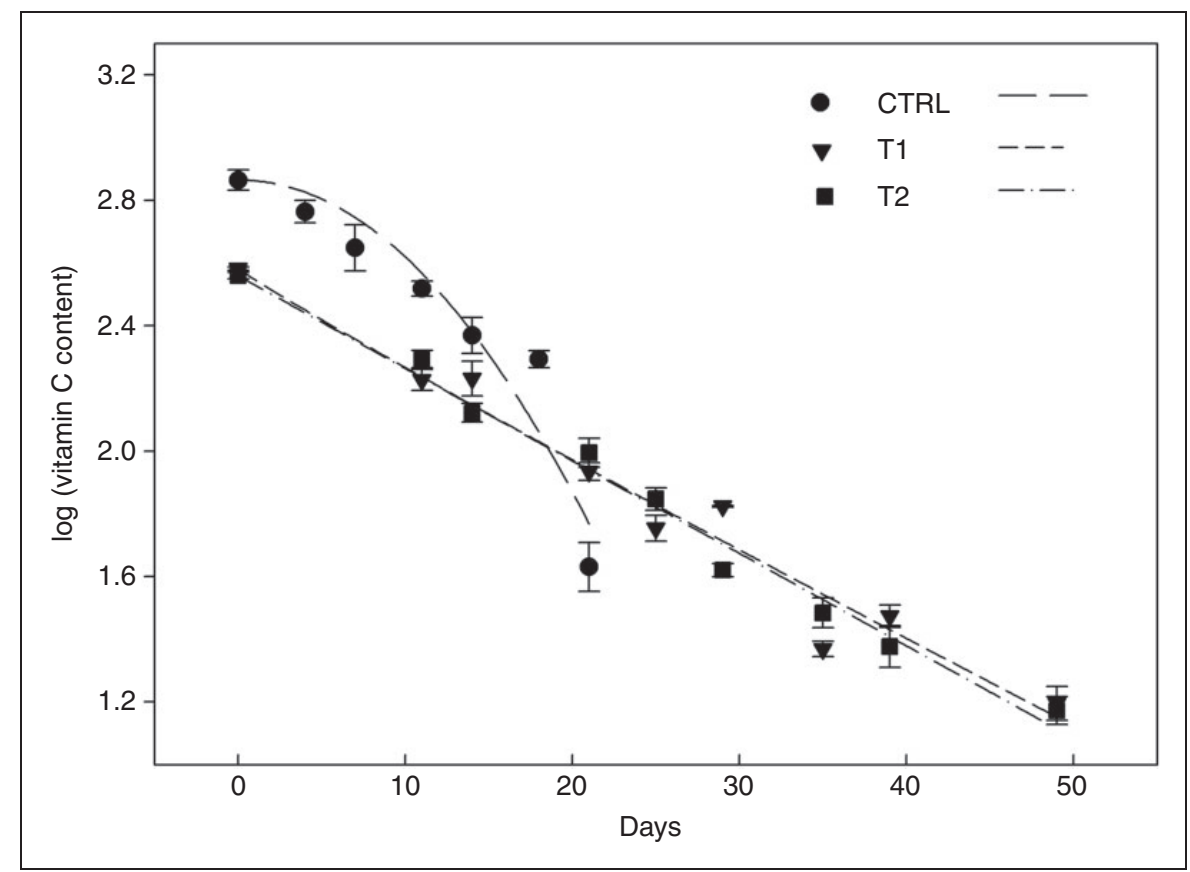

Figure 2. Total vitamin $C$ (logarithmic scale) in untreated (CTRL) and heat-treated (T1 and T2) green vegetables smoothies stored at $5^{\circ} \mathrm{C}(\mathrm{n}=5 \pm \mathrm{SD})$. Experimental (points) and fitted values are derived from the Weibullian model (lines). 
to DHA which exhibits antioxidant properties in addition to antiscorbutic activity equivalent to that of ascorbic acid (Munyaka et al., 2010). During smoothie preparation blending disrupts plant cells allowing enzymes to access their substrates located in different plant cell locations. Accordingly, no ascorbic acid was detected in CTRL or thermally treated smoothies on processing day due to the rapid ascorbic acid to DHA enzymatic conversion (data not shown). The ascorbic acid to DHA conversion was possible since the applied thermal treatments did not completely inactivate the vitamin $\mathrm{C}$ oxidative enzymes as previously reported (Munyaka et al., 2010). It is well known that vitamin $\mathrm{C}$ is a very thermolabile vitamin (Lee and Kader, 2000). Accordingly, heat treatments reduced by approximately $50 \%$ the initial total vitamin $\mathrm{C}$ level of the smoothie without significant differences among treatments. Lower vitamin $\mathrm{C}$ content $\left(430 \mathrm{mgl}^{-1}\right)$ has been reported in a green smoothie (40\% kiwifruits, $7 \%$ fennels, $8 \%$ spinach and $15 \%$ papaya) which was treated at $80^{\circ} \mathrm{C}$ for $10 \mathrm{~min}$ (Di Cagno et al., 2011).

Total vitamin C losses of $76-87 \%$ were observed after seven days at $15^{\circ} \mathrm{C}$ without significant differences among samples (data not shown). However, latter great total vitamin $\mathrm{C}$ loss was reduced by $50 \%$ when CTRL samples were stored at $5{ }^{\circ} \mathrm{C}$. Similarly, storage of T1 and $\mathrm{T} 2$ samples at $5^{\circ} \mathrm{C}$ reduced by 1.5 - and 2-fold, respectively, the total vitamin C losses (85-91\%) observed after 11 days at $15^{\circ} \mathrm{C}$. CTRL and heat-treated samples showed total vitamin $\mathrm{C}$ contents of $42.7 \pm 7.3$ and $14.9 \pm 1.5 / 15.7 \pm 1.9 \mathrm{mg} \mathrm{kg}^{-1}$ fw after 21 and 49 days at $5{ }^{\circ} \mathrm{C}$, respectively, without differences among thermal treatments.

According to $\mathrm{FAO} / \mathrm{WHO}$, vitamin $\mathrm{C}$ intake is required to promote optimal health $(\mathrm{FAO} / \mathrm{WHO}$, 2004). A $250 \mathrm{~g}$ portion of this smoothie provides approximately $400 \%$ of the RNIs for vitamin C for adults and $260 \%$ for lactating women which is the population group with the highest RNIs for vitamin $\mathrm{C}(\mathrm{FAO} /$ WHO, 2004). However, vitamin $\mathrm{C}$ of fruit and vegetables beverages may greatly decrease during storage due to oxidative and enzymatic degradative processes, among others (Lee and Kader, 2000). Accordingly, it is important to predict the vitamin $\mathrm{C}$ degradation during the smoothie storage to know the maximum storage time that ensures the minimum vitamin $\mathrm{C}$ RNIs. Experimental data related to total vitamin $\mathrm{C}$ changes during storage at $5{ }^{\circ} \mathrm{C}$ were well fitted $\left(\mathrm{R}^{2}{ }_{\text {ADJ }}>95 \%\right.$; Table 2) with the cumulative form of the Weibull distribution (equation (1)). Calculations were estimated with the GInaFiT application (version 1.6) for Microsoft Excel (Geeraerd et al., 2005). However

$$
\log _{10} X=\log _{10} X_{0}-\left(\frac{t}{\delta}\right)^{p}
$$

Table 2. Estimates of Weibullian distribution parameters $\delta$ and $p$ and adjusted $R^{2}$ for vitamin $C$ content changes in untreated (CTRL) and heat-treated (T1 and T2) green vegetables smoothies during storage at $5^{\circ} \mathrm{C}$

\begin{tabular}{llll}
\hline & $\delta$ & $p$ & $R^{2}$ ADJ \\
\hline CTRL & 20.07 & 2.02 & 0.92 \\
T1 & 33.62 & 0.95 & 0.96 \\
T2 & 33.88 & 0.98 & 0.99 \\
\hline
\end{tabular}

where $\mathrm{X}$ is the vitamin $\mathrm{C}$ content, $\mathrm{X}_{0}$ is the initial vitamin $\mathrm{C}$ content, $t$ is the storage time (days), $\delta$ represents the time needed for the first decimal reduction (days) and $p$ is the shape parameter. Table 2 shows the calculated parameters $\delta$ and $p$ for the vitamin $\mathrm{C}$ curves determined with the Weibull model. While vitamin $\mathrm{C}$ curves of CTRL smoothie stored at $5^{\circ} \mathrm{C}$ showed downward concavity $(p>1), \mathrm{T} 1$ and T2 samples showed upward concavity $(p<1)$. Since total vitamin $\mathrm{C}$ content did not significantly change during storage at $15^{\circ} \mathrm{C}$ and no intermediate data were analysed between processing and seventh day of storage these data were not modelled. The maximum storage time at $5^{\circ} \mathrm{C}$ of a smoothie portion of $250 \mathrm{~g}$ that ensured the minimum vitamin $\mathrm{C}$ RNI (45 mg day ${ }^{-1}$ ) for CTRL T1 and T2 samples was 15.2, 10.7 and 10.8 days, respectively. At the end of CTRL and T1-T2 smoothies shelf-lives the vitamin C contents still represented 30 and $10 \%$ of the RNIs, respectively. As observed, total vitamin $\mathrm{C}$ degradation of thermal-treated smoothies was higher than CTRL samples. DHA can be rapidly and irreversibly hydrolysed to 2,3-diketogulonoic acid (2,3-DKG) hence losing its antiscorbutic activity (Deutsch,2000). The applied thermal treatments may increase the extraction of those compounds involved in the vitamin $\mathrm{C}$ degradation to 2,3-DKG increasing its reaction rates according to the observed reduced vitamin $\mathrm{C}$ levels of thermal-treated samples during storage.

\section{Phenolic compounds}

The phenolic compounds of the smoothie were identified by their chromatographic behaviour, UV spectra and HPLC/MS (Supplementary Materials 3 and 4). Initial total phenolic content (calculated as the sum of identified phenolics) of CTRL smoothie was $151.1 \pm 4.0 \mathrm{mg} \mathrm{kg}^{-1} \mathrm{fw}$ (Table 3). The initial total phenolic content of CTRL was increased by 44 and $36 \%$ after $\mathrm{T} 1$ and $\mathrm{T} 2$ treatments, respectively. The apparent increases of these phenolic compounds could be primarily due to the cell membrane and wall ruptures of plant material, releasing phytochemicals from the insoluble portion of the smoothie. The lower phenolic 


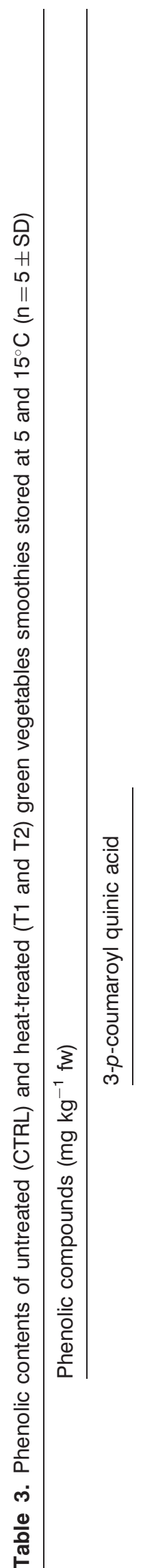

끈 $\frac{\infty}{0}$

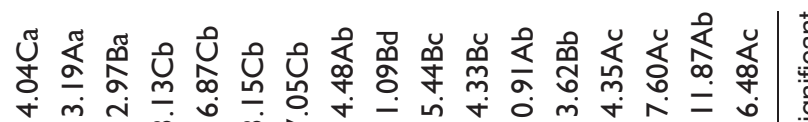

중 릉

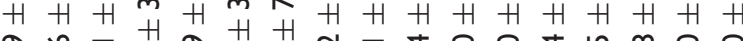
ơ นำ

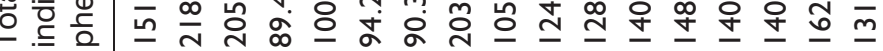
ชั

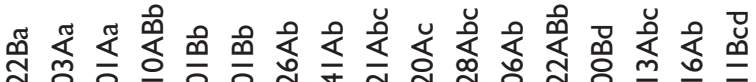

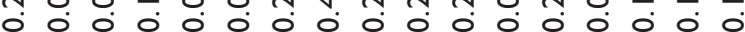

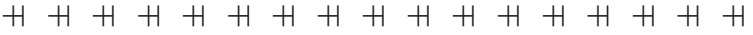

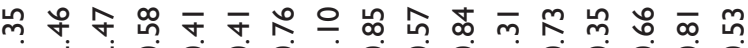
กิะ

ठิ min 은 은 들

究응

긍

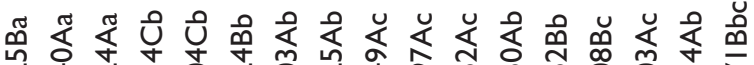
ஸึ่ 웜 t

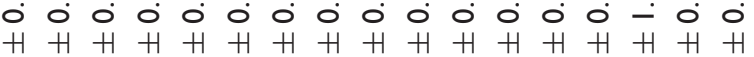

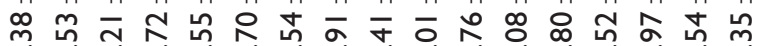

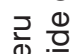
交

호으응

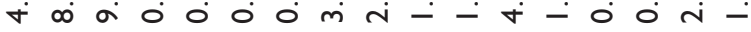
m $\mathrm{H}+\mathrm{H} H \mathrm{H} H \mathrm{H}+\mathrm{H}+\mathrm{H}$ H H H H H H ㄴ. ㅇํㅇ

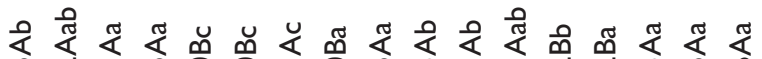

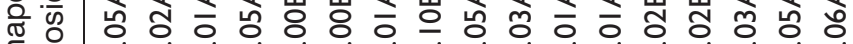

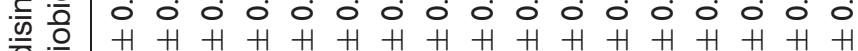
$\stackrel{-1}{D}$ กี

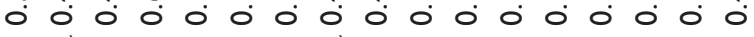

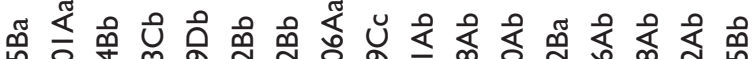
Uु + i H

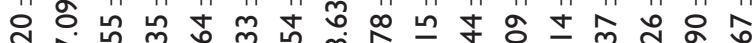
ம் 으 Uึ ڤึ 寸

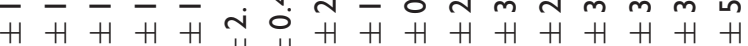

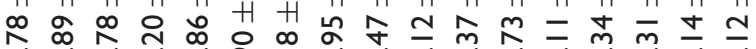

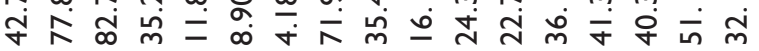

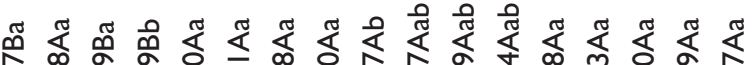
సิ ळ응 후

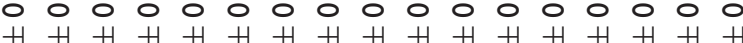

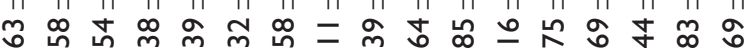

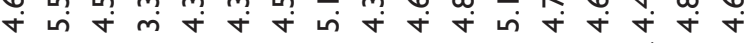

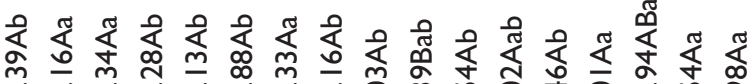
$\frac{0}{\frac{0}{0}}$ - o 0 j

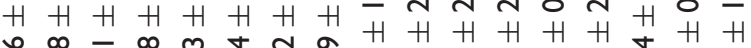

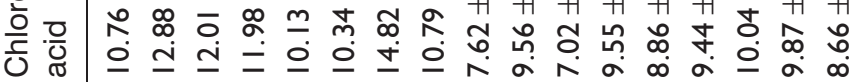

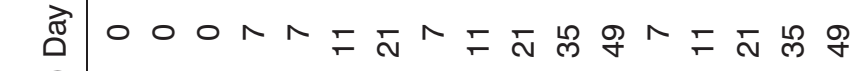

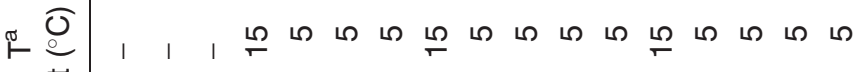
क⿺辶万

菢 品 $\cong \stackrel{\frac{\vec{\alpha}}{\sigma}}{0}$

F

$\stackrel{N}{\llcorner}$ 
increment of T2 samples may be owed to the lower treatment time which did not produce great cell disruption as observed in T1 samples. Accordingly, the content of the main phenolic acids (3-p-coumaroyl quinic, chlorogenic and sinapic acids) remained unchanged after $\mathrm{T} 2$ treatment. The greatest phenolic acids increments after $\mathrm{T} 1 / \mathrm{T} 2$ treatments were those corresponding to 1-sinapoyl-2-feruloylgentiobioside, 1,2,2'-trisinapoylgentiobioside, 3-p-coumaroyl quinic acid (1) and 1,2'-disinapoyl-2-feruloylgentiobioside with 153/98, $95 / 110,82 / 94$ and $82 / 83 \%$ compared to the respective initial contents of CTRL samples.

Attending to phenolic acids changes during storage, the levels of 3-p-coumaroyl quinic acid (1), 1-sinapoyl2-feruloylgentiobioside, 1,2,2'-trisinapoylgentiobioside and 1,2'-disinapoyl-2-feruloylgentiobioside smoothies decreased throughout storage for both treatments and storage temperatures registering the greatest losses in the first seven days of storage. Storage at $5{ }^{\circ} \mathrm{C}$ of CTRL smoothies greatly reduced the 3-p-coumaroyl quinic acid (2) and 1-sinapoyl-2-feruloylgentiobioside losses of 57 and $65 \%$ at $15^{\circ} \mathrm{C}$ to 16 and $27 \%$, respectively. However, 3-p-coumaroyl quinic acid (1) and 1,2'disinapoyl-2-feruloylgentiobioside showed the opposite behaviour with losses of $18-57$ and $70-72 \%$ in those CTRL smoothies stored for seven days at 15 and $5{ }^{\circ} \mathrm{C}$, respectively. On the other side, 1,2,2'-trisinapoylgentiobioside and 1,2-disinapoylgentiobioside levels of CTRL samples decreased by approximately 85 and $33 \%$, respectively, after seven days independently of the storage temperature. Among thermally treated samples sinapic acid contents did not change after 49 or seven days at 5 or $15^{\circ} \mathrm{C}$, respectively. In general, T1 samples registered sevenfold lower 3-p-coumaroyl quinic acid (1) losses and 1.1-1.6-fold lower losses for 1-sinapoyl2-feruloylgentiobioside, 1,2,2'-trisinapoylgentiobioside and 1,2'-disinapoyl-2-feruloylgentiobioside regarding T2 samples after seven days either at 5 or $15^{\circ} \mathrm{C}$. Accordingly, among thermal treatment conditions, the lower temperature treatment better retained latter four phenolic acids during storage compared to higher temperature treatment time. 3-p-coumaroyl quinic (2) and sinapic acids did not register great changes throughout storage in all samples at $5{ }^{\circ} \mathrm{C}$ or thermally treated samples stored at $15^{\circ} \mathrm{C}$. However, 3-p-coumaroyl quinic (2) and sinapic acids decreased by 57 and $27 \%$, respectively, in CTRL samples stored for seven days at $15^{\circ} \mathrm{C}$. Attending to chlorogenic acid, no significant changes in CTRL samples were observed for 7-11 days at 15 or $5^{\circ} \mathrm{C}$. Chlorogenic acid of CTRL samples stored at $5{ }^{\circ} \mathrm{C}$ increased from day 11 to day 21 by $38 \%$. However, $\mathrm{T} 1$ and $\mathrm{T} 2$ samples stored at $15^{\circ} \mathrm{C}$ registered 16 and $26 \%$ chlorogenic acid losses after seven days, respectively. PAL is the key enzyme in the phenols biosynthesis pathway which is activated under abiotic stresses (Cisneros-Zevallos, 2003) such as the wounding produced during smoothie blending. Accordingly, PAL was activated in untreated red smoothies after 10 days of storage at $5{ }^{\circ} \mathrm{C}$ being this enzyme activation, retarded to 20-30 days either at 5 or $20^{\circ} \mathrm{C}$ in thermally treated samples (similar conditions as T1) (RodríguezVerástegui et al., 2015). Furthermore, PAL activation of CTRL samples was double of that from heat-treated samples (Rodríguez-Verástegui et al., 2015). Accordingly, the observed chlorogenic acid increment in CTRL samples may be owed to PAL activation. However, a lower PAL activation of heat-treated samples may lead to the observed unchanged levels in $\mathrm{T} 1$ and $\mathrm{T} 2$ samples stored at $5^{\circ} \mathrm{C}$ and reduced levels in those samples stored at $15^{\circ} \mathrm{C}$ as a negative counterbalance between chlorogenic acid biosynthesis and its degradation at this high storage temperature. As it has been previously reviewed the changes of the phenolic profile of fruit blends during storage greatly depend on the phenolic compound and storage conditions as also observed in our smoothie data (Chen et al., 2013).

Conclusively, phenolic contents increased after thermal treatment, in a greater extend in $\mathrm{T} 1$ samples, being this phenolic increment associated with subsequent enhanced bioaccessibility in the gastrointestinal tract (Bugianesi et al., 2004). In general, phenolic levels decreased during storage, except chlorogenic and sinapic acids, registering the greatest losses in the first 7-11 days showing $\mathrm{T} 1$ samples lower degradation rates.

\section{TAC}

The initial TAC of CTRL smoothie obtained by FRAP, ABTS and DPPH were $234.2 \pm 20.3$, $395.7 \pm 22.4$ and $54.4 \pm 16.6 \mathrm{mg}$ Trolox equivalents $\mathrm{kg}^{-1}$ fw, respectively (Table 4). Phenolic compounds are the major contributors to the antioxidant properties of fresh produce (Cisneros-Zevallos, 2003). Antioxidant capacity of a food product may greatly differ depending on the analytical method used (Prior et al., 2005). Accordingly, a Pearson correlation using total phenolic content and TAC data during storage was used to determine which TAC method was better correlated to total phenolic content. FRAP method achieved the best correlations $\left(r^{2}=0.67\right)$ closely followed by ABTS $\left(\mathrm{r}^{2}=0.53\right)$. Consequently, only FRAP data are discussed.

Contrary to the apparent increase of total phenolic content after thermal treatment, TAC did not register significant differences after heating. Similarly, Keenan et al. (2010) did not find significant TAC changes after heat treatment $\left(70^{\circ} \mathrm{C}\right.$ for $\left.10 \mathrm{~min}\right)$ of a fruit smoothie while total phenolic content increased. Vitamin $\mathrm{C}$ also plays an important contribution to the TAC of the 
Table 4. Total antioxidant capacity (FRAP, ABTS and DPPH methods) of untreated (CTRL) and heat-treated (T1 and T2) green vegetables smoothies stored at 5 and $15^{\circ} \mathrm{C}(n=5 \pm$ SD)

\begin{tabular}{lcclll}
\hline & & & \multicolumn{3}{l}{ Total antioxidant capacity $\left(\mathrm{mg}\right.$ Trolox equivalents $\left.\mathrm{kg}^{-1} \mathrm{fw}\right)$} \\
\cline { 5 - 6 } Treatment & $\mathrm{T}^{\mathrm{a}}\left({ }^{\circ} \mathrm{C}\right)$ & Day & FRAP & ABTS & DPPH \\
\hline CTRL & - & 0 & $234.2 \pm 20.3 \mathrm{Aa}$ & $395.7 \pm 22.4 \mathrm{Ab}$ & $54.4 \pm 16.6 \mathrm{Ab}$ \\
T1 & - & 0 & $247.1 \pm 12.4 \mathrm{Aa}$ & $411.4 \pm 34.8 \mathrm{Aa}$ & $85.1 \pm 23.8 \mathrm{Aa}$ \\
T2 & - & 0 & $231.0 \pm 5.9 \mathrm{Aab}$ & $390.0 \pm 39.2 \mathrm{Aa}$ & $69.1 \pm 6.6 \mathrm{Aa}$ \\
CTRL & 15 & 7 & $237.1 \pm 18.7 \mathrm{ABa}$ & $458.1 \pm 25.0 \mathrm{Aa}$ & $97.7 \pm 18.3 \mathrm{ABa}$ \\
& 5 & 7 & $218.1 \pm 14.2 \mathrm{Bab}$ & $383.2 \pm 7.1 \mathrm{Bb}$ & $35.1 \pm 15.1 \mathrm{Cbc}$ \\
& 5 & 11 & $127.9 \pm 18.2 \mathrm{Bc}$ & $251.9 \pm 33.2 \mathrm{Ac}$ & $17.5 \pm 7.5 \mathrm{Bc}$ \\
& 5 & 21 & $174.4 \pm 28.1 \mathrm{Bbc}$ & $372.6 \pm 38.0 \mathrm{Ab}$ & $13.8 \pm 11.9 \mathrm{Bc}$ \\
T1 & 15 & 7 & $260.4 \pm 14.9 \mathrm{Aa}$ & $352.9 \pm 18.2 \mathrm{Ba}$ & $119.5 \pm 13.5 \mathrm{Aa}$ \\
& 5 & 11 & $226.6 \pm 0.7 \mathrm{Aa}$ & $287.8 \pm 21.8 \mathrm{Ab}$ & $43.5 \pm 11.9 \mathrm{Ab}$ \\
& 5 & 21 & $243.4 \pm 20.9 \mathrm{Aa}$ & $415.0 \pm 44.6 \mathrm{Aa}$ & $45.2 \pm 4.0 \mathrm{Ab}$ \\
& 5 & 35 & $255.5 \pm 19.8 \mathrm{Aa}$ & $302.6 \pm 18.1 \mathrm{Ab}$ & $56.9 \pm 8.5 \mathrm{Aab}$ \\
& 5 & 49 & $249.8 \pm 19.0 \mathrm{Aa}$ & $326.9 \pm 13.4 \mathrm{Ab}$ & $70.3 \pm 9.4 \mathrm{Aab}$ \\
T2 & 15 & 7 & $230.5 \pm 15.7 \mathrm{ABa}$ & $379.4 \pm 38.5 \mathrm{Ba}$ & $77.6 \pm 6.8 \mathrm{Ba}$ \\
& 5 & 11 & $152.3 \pm 8.3 \mathrm{Bc}$ & $260.1 \pm 8.2 \mathrm{Ac}$ & $37.7 \pm 2.9 \mathrm{ABb}$ \\
& 5 & 21 & $204.5 \pm 21.0 \mathrm{ABb}$ & $388.0 \pm 8.5 \mathrm{Aa}$ & $49.1 \pm 3.9 \mathrm{Aab}$ \\
& 5 & 35 & $272.2 \pm 19.7 \mathrm{Aa}$ & $289.3 \pm 9.8 \mathrm{Abc}$ & $45.0 \pm 17.6 \mathrm{Aab}$ \\
& 5 & 49 & $248.7 \pm 22.6 \mathrm{Aab}$ & $337.3 \pm 30.4 \mathrm{Aab}$ & $54.0 \pm 13.8 \mathrm{Aab}$ \\
& 5 & & &
\end{tabular}

FRAP: ferric reducing antioxidant power; ABTS: 2,2'-azino-bis (3-ethylbenzothiazoline-6-sulphonic acid); DPPH: 2,2-diphenyl-1picrylhydrazil.

Different capital letters denote significant differences $(P \leq 0.05)$ among treatments stored at the same temperature for the same sampling day. Different lowercase letters denote significant differences $(P \leq 0.05)$ among sampling days for the same treatment stored at the same temperature.

smoothie. Accordingly, the unchanged TAC may be a result of the above described vitamin $\mathrm{C}$ reduction after thermal treatment.

The TAC levels of all samples remained quite constant throughout storage at both temperatures, except CTRL samples stored at $5{ }^{\circ} \mathrm{C}$ which showed a TAC decrease of $45 \%$ after 11 days followed by an increase registering final levels of $174.4 \pm 28.1 \mathrm{mg}$ Trolox equivalents $\mathrm{kg}^{-1} \mathrm{fw}$. Similarly, Keenan et al. (2010) reported TAC decreases in heat-treated $\left(70^{\circ} \mathrm{C}\right.$ for $10 \mathrm{~min}$ ) fruit smoothies after 10 days at $4{ }^{\circ} \mathrm{C}$. Accordingly, thermal treatments avoided TAC losses of the smoothie during storage at both temperatures probably due to the heat inactivation of enzymes involved in the degradation of antioxidant compounds.

\section{Intact glucosinolates}

The glucosinolates of the smoothie were identified by their chromatographic behaviour, UV spectra and HPLC/MS (Supplementary Materials 3 and 5). The initial total glucosinolate content of CTRL samples was $128.77 \pm 16.26 \mathrm{mg} \mathrm{kg}^{-1}$ (Table 5). Total glucosinolate content was not affected by any of the thermal treatments. However, different patterns were observed among individual glucosinolates. Isothiocyanates are the biologically active breakdown products from glucosinolates which lack of those chemopreventive properties. However, the presence of the epithiospecifier protein (ESP), among other factors, may lead to other breakdown products different from isothiocyanates. The thermal treatments applied may ensure the thermal degradation of ESP since this protein was completely inactivated in broccoli florets after $60^{\circ} \mathrm{C}$ for 5 min (Matusheski et al., 2004), being the ESP inactivation probably even enhanced in our smoothie due to better heat transmission. Regarding to structure-activity relationships, it was generally observed that glucosinolates with a hydroxyl function in the side chain are more labile compared to their corresponding nonhydroxylated relatives (Hanschen et al., 2014). Accordingly, while glucobrassicin content did not change for any of the thermal treatments, 4-hydroxyglucobrassicin was reduced by $29 \%$ after T1 treatment. Furthermore, T1 treatment induced 4-methoxyglucobrassicin decrease of $49 \%$. T2 treatment did not induce significant changes among glucosinolates contrary to T1. Glucoraphanin content of the smoothie increased by $36 \%$ after $\mathrm{T} 1$ treatment. It has been widely reported that aliphatic glucosinolates (such as 
Table 5. Intact glucosinolates contents of untreated (CTRL) and heat-treated (T1 and T2) green vegetables smoothies stored at 5 and $15^{\circ} \mathrm{C}(\mathrm{n}=5 \pm \mathrm{SD})$

\begin{tabular}{|c|c|c|c|c|c|c|c|}
\hline \multirow[b]{2}{*}{ Treatment } & \multirow[b]{2}{*}{$\begin{array}{l}\mathrm{T}^{\mathrm{a}} \\
\left({ }^{\circ} \mathrm{C}\right)\end{array}$} & \multirow[b]{2}{*}{ Day } & \multicolumn{5}{|c|}{ Glucosinolates (mg kg $\left.{ }^{-1} \mathrm{fw}\right)$} \\
\hline & & & Glucoraphanin & Glucobrassicin & $\begin{array}{l}\text { 4-Hydroxygluco } \\
\text { brassicin }\end{array}$ & $\begin{array}{l}\text { 4-Methoxy } \\
\text { glucobrassicin }\end{array}$ & $\begin{array}{l}\text { Total } \\
\text { glucosinolates }\end{array}$ \\
\hline CTRL & - & 0 & $4.48 \pm 0.3 \mathrm{IBa}$ & $95.25 \pm 22.33 \mathrm{Aa}$ & $16.96 \pm 0.38 \mathrm{Aa}$ & $\mathrm{I} .12 \pm 0.09 \mathrm{Aa}$ & $\mathrm{II} .8 \mathrm{I} \pm 16.26 \mathrm{Aa}$ \\
\hline T1 & - & 0 & $6.08 \pm 0.57 \mathrm{Aa}$ & $\mathrm{I} 08.30 \pm 5.5 \mathrm{IAa}$ & $\mathrm{I} 2.03 \pm 0.5 \mathrm{IBa}$ & $0.57 \pm 0.1 \mathrm{IBa}$ & $126.98 \pm 5.53 \mathrm{Aa}$ \\
\hline T2 & - & 0 & $4.18 \pm 0.38 \mathrm{Bab}$ & $123.14 \pm 1.50 \mathrm{Aa}$ & $17.39 \pm 0.63 \mathrm{Aa}$ & $\mathrm{I} .33 \pm 0.28 \mathrm{Aa}$ & $\mathrm{I} 44.04 \pm \mathrm{I} .23 \mathrm{Aa}$ \\
\hline \multirow[t]{4}{*}{ CTRL } & 15 & 7 & $\mathrm{I} .57 \pm \mathrm{I} .5 \mathrm{IABb}$ & $\mathrm{I} 0 \mathrm{I} .02 \pm 2.6 \mathrm{IAa}$ & $7.18 \pm 0.70 \mathrm{Cb}$ & $0.18 \pm 0.10 \mathrm{Ab}$ & $109.94 \pm 3.10 \mathrm{ABa}$ \\
\hline & 5 & 7 & $3.15 \pm 0.39 \mathrm{Aab}$ & $108.52 \pm I I . \mid 4 \mathrm{Aa}$ & $10.03 \pm 0.54 \mathrm{ABb}$ & $0.85 \pm 0.23 \mathrm{Aa}$ & $122.55 \pm 10.49 \mathrm{Aa}$ \\
\hline & 5 & 11 & $\mathrm{I} .84 \pm 1.2 \mathrm{IAbc}$ & $107.08 \pm 4.4 \mathrm{IBa}$ & $8.38 \pm 0.7 \mathrm{IBc}$ & $1.28 \pm 1.54 \mathrm{Aa}$ & $\mathrm{I} \mid 8.57 \pm 6.7 \mathrm{IBa}$ \\
\hline & 5 & 21 & $0.83 \pm 0.58 \mathrm{Ac}$ & $99.87 \pm 3.53 \mathrm{Aa}$ & $7.36 \pm 0.49 A c$ & $1.70 \pm 0.36 \mathrm{Aa}$ & $109.76 \pm 3.85 \mathrm{Aa}$ \\
\hline \multirow[t]{5}{*}{$\mathrm{T} 1$} & 15 & 7 & $0.93 \pm 0.1 \mathrm{IBb}$ & $95.79 \pm 4.84 \mathrm{Aa}$ & $8.7 \mathrm{I} \pm 0.84 \mathrm{BCb}$ & $0.03 \pm 0.04 \mathrm{Ab}$ & $105.46 \pm 5.62 \mathrm{Bb}$ \\
\hline & 5 & 11 & $0.07 \pm 0.07 \mathrm{Ad}$ & $80.06 \pm 0.07 \mathrm{Cb}$ & $12.65 \pm 0.07 \mathrm{Aa}$ & $0.83 \pm 0.16 \mathrm{Aa}$ & $93.61 \pm 1.46 C c$ \\
\hline & 5 & 21 & $0.65 \pm 0.17 A d$ & $102.30 \pm 3.16 \mathrm{Aa}$ & $7.12 \pm 0.94 A c$ & $0.40 \pm 0.47 \mathrm{Ba}$ & $110.47 \pm 3.50 \mathrm{Ab}$ \\
\hline & 5 & 35 & $1.97 \pm 0.15 \mathrm{Ac}$ & $71.26 \pm 6.36 \mathrm{Ab}$ & $8.14 \pm 0.21 \mathrm{Bc}$ & $0.17 \pm 0.06 \mathrm{Aa}$ & $81.55 \pm 6.23 \mathrm{Ad}$ \\
\hline & 5 & 49 & $2.89 \pm 0.38 \mathrm{Ab}$ & $58.8 \mathrm{I} \pm 1.87 \mathrm{Bc}$ & $9.59 \pm 0.50 \mathrm{Ab}$ & $0.29 \pm 0.2 \mathrm{IAa}$ & $71.58 \pm 1.76 \mathrm{Bd}$ \\
\hline \multirow[t]{5}{*}{ T2 } & 15 & 7 & $1.70 \pm 0.08 \mathrm{ABa}$ & $104.98 \pm 6.85 \mathrm{Ab}$ & $11.30 \pm 1.19 \mathrm{Ab}$ & $1.95 \pm 1.94 \mathrm{Aa}$ & $119.94 \pm 4.28 \mathrm{ABb}$ \\
\hline & 5 & 11 & $0.70 \pm 0.30 \mathrm{Ac}$ & $|25.3| \pm 6.32 \mathrm{Aa}$ & $9.83 \pm 1.40 \mathrm{Bb}$ & $1.16 \pm 0.14 \mathrm{Aa}$ & $|37.0| \pm 5.65 \mathrm{Aa}$ \\
\hline & 5 & 21 & $0.54 \pm 0.06 \mathrm{Ac}$ & $105.36 \pm 2.36 \mathrm{Ab}$ & $9.01 \pm 1.56 \mathrm{Ab}$ & $1.14 \pm 0.19 \mathrm{ABa}$ & $116.05 \pm 1.28 \mathrm{Ab}$ \\
\hline & 5 & 35 & $1.39 \pm 0.13 \mathrm{Bbc}$ & $83.50 \pm 9.48 A c$ & $10.50 \pm 0.77 \mathrm{Ab}$ & $1.13 \pm 1.25 \mathrm{Aa}$ & $96.52 \pm 10.74 \mathrm{Ac}$ \\
\hline & 5 & 49 & $2.56 \pm 0.52 \mathrm{Aa}$ & $73.83 \pm 7.62 \mathrm{Ac}$ & $9.22 \pm 0.64 \mathrm{Ab}$ & $\mathrm{I} .57 \pm \mathrm{I} .5 \mathrm{IAa}$ & $87.19 \pm 9.21 \mathrm{Ac}$ \\
\hline
\end{tabular}

Different capital letters denote significant differences $(P \leq 0.05)$ among treatments stored at the same temperature for the same sampling day. Different lowercase letters denote significant differences $(P \leq 0.05)$ among sampling days for the same treatment stored at the same temperature.

glucoraphanin) are more heat stable than indole glucosinolates (such as glucobrassicin 4-hydroxyglucobrassicin and 4-methoxyglucobrassicin) for temperature treatments below $110^{\circ} \mathrm{C}$ (Hanschen et al., 2014). Therefore, the apparent glucoraphanin increment may be owed to a better heat stability of this glucosinolate together with an enhanced extractability of this compound during $\mathrm{T} 1$, the longest treatment.

Glucosinolates contents of CTRL samples did not change after seven days at $5^{\circ} \mathrm{C}$, except 4-hydroxyglucobrassicin which decreased by $41 \%$. However, storage of CTRL samples at $15^{\circ} \mathrm{C}$ for seven days induced 58,65 and $84 \%$ decreases of 4-hydroxyglucobrassicin, glucoraphanin and 4-methoxyglucobrassicin, respectively, although glucoraphanin was preserved. Similarly, Rangkadilok et al. (2002) reported a 50\% decrease in glucoraphanin in 'Marathon' heads after seven days at $15^{\circ} \mathrm{C}$, but no decrease after seven days at $4{ }^{\circ} \mathrm{C}$. The breakdown of glucosinolates by myrosinase is usually a very rapid event which is greatly enhanced after mechanical homogenisation such as smoothie preparation (Verkerk et al., 1997). In agreement to our data, myrosinase activity of 'Marathon' heads was probably greatly reduced at $4^{\circ} \mathrm{C}$ while it was enhanced at $15^{\circ} \mathrm{C}$. Glucosinolates levels from day 7 to day 21 did not change at $5{ }^{\circ} \mathrm{C}$ except glucoraphanin that greatly decreased by $81 \%$. Similarly, glucoraphanin showed the greatest losses among glucosinolates in broccoli florets stored at $4{ }^{\circ} \mathrm{C}$ (Verkerk et al., 2001).

Regarding to thermal-treated samples, no great glucosinolates changes were observed after 11 days at $5{ }^{\circ} \mathrm{C}$ except 4-hydroxyglucobrassicin of $\mathrm{T} 2$ samples that, similarly to CTRL samples, decreased by $43 \%$. The observed 4-hydroxyglucobrassicin reduction may be owed to the commented higher degradation of these glucosinolates with a hydroxyl function. From day 11 to the end of storage at $5^{\circ} \mathrm{C}$, low glucosinolates losses were observed in those thermal-treated samples $(<26 \%)$. In the same way, no great glucosinolates losses $(<30 \%)$ were observed in those $\mathrm{T} 1$ and $\mathrm{T} 2$ samples stored at $15^{\circ} \mathrm{C}$ for seven days. Van Eylen et al. (2007) reported a residual myrosinase activity of $23 \%$ in broccoli juice treated at $60^{\circ} \mathrm{C}$ for $3 \mathrm{~min}$. Accordingly, the low glucosinolates losses of thermal-treated samples during storage at low temperature may be owed to a complete myrosinase inactivation.

Conclusively, short-time/high temperature treatment (T2) did not induce individual glucosinolates losses regarding T1 samples ( $<49 \%$ losses). The glucosinolates degradation observed in CTRL samples during storage was greatly reduced in both thermal-treated samples. 


\section{CONCLUSIONS}

This study presents a green fresh vegetables smoothie with excellent nutritional, microbial and physicochemical quality during a shelf-life of 49 days at $5^{\circ} \mathrm{C}$. Mild thermal treatments were necessary during processing to preserve its quality achieving T2 $\left(45 \mathrm{~s}\right.$ at $\left.90^{\circ} \mathrm{C}\right)$ better microbial reductions and health-promoting compounds preservation (related to phenolics and glucosinolates contents). Furthermore, low temperature storage at $5^{\circ} \mathrm{C}$ is recommended to preserve quality and safety. A $250 \mathrm{~g}$ portion of this green smoothie can highly cover the established RNIs for DF, minerals and vitamin $\mathrm{C}$ of different population groups.

\section{ACKNOWLEDGEMENTS}

We are grateful to M. Otón for his skilful technical assistance.

\section{DECLARATION OF CONFLICTING INTERESTS}

The author(s) declared no potential conflicts of interest with respect to the research, authorship, and/or publication of this article.

\section{FUNDING}

The author(s) disclosed receipt of the following financial support for the research, authorship, and/or publication of this article: The authors are grateful to Spanish Ministry of Economy and Competitiveness (MINECO) Project AGL2013-48830-C2-1-R and FEDER for financial support.

\section{REFERENCES}

Anand P, Kunnumakara AB, Sundaram C, Harikumar KB, Tharakan ST, Lai OS, et al. (2008). Cancer is a preventable disease that requires major lifestyle changes. Pharmaceutical Research 25: 2097-2116.

Barba FJ, Esteve MJ and Frigola A. (2012). High-pressure treatment effect on physicochemical and nutritional properties of fluid foods during storage: A review. Comprehensive Reviews in Food Science and Food Safety 11: 307-322.

Basu S, Shivhare US, Singh TV and Beniwal VS. (2011). Rheological, textural and spectral characteristics of sorbitol substituted mango jam. Journal of Food Engineering 105: 503-512.

Benzie IF and Strain JJ. (1999). Ferric reducing/antioxidant power assay: Direct measure of total antioxidant activity of biological fluids and modified version for simultaneous measurement of total antioxidant power and ascorbic acid concentration. Methods in Enzymology 299: 15-27.

Boeing H, Bechthold A, Bub A, Ellinger S, Haller D, Kroke A, et al. (2012). Critical review: Vegetables and fruit in the prevention of chronic diseases. European Journal of Nutrition 51: 637-663.
Brand-Williams W, Cuvelier ME and Berset C. (1995). Use of free radical method to evaluate antioxidant activity. $L W T$ - Food Science and Technology 28: 25-30.

Bugianesi R, Salucci M, Leonardi C, Ferracane R, Catasta G, Azzini E, et al. (2004). Effect of domestic cooking on human bioavailability of narigerin, chlorogenic acid, lycopene and beta-carotene in cherry tomatoes. European Journal of Nutrition 43: 360-366.

Buzrul S, Alpas H, Largeteau A and Demazeau G. (2008). Inactivation of Escherichia coli and Listeria innocua in kiwifruit and pineapple juices by high hydrostatic pressure. International Journal of Food Microbiology 124: 75-278.

Cano A, Hernández-Ruíz J, García-Cánovas F, Acosta M and Arnao MB. (1998). An end-point method for estimation of the total antioxidant activity in plant material. Phytochemical Analysis 9: 196-202.

Castillejo N, Martínez-Hernández GB, Gómez PA, Artés F and Artés-Hernández F. (2016). Red fresh vegetables smoothies with extended shelf life as an innovative source of health-promoting compounds. Journal of Food Science and Technology 53: 1475-1486.

Chen Y, Yu LJ and Rupasinghe HPV. (2013). Effect of thermal and non-thermal pasteurisation on the microbial inactivation and phenolic degradation in fruit juice: A mini-review. Journal of the Science of Food and Agriculture 93: 981-986.

Cisneros-Zevallos L. (2003). The use of controlled postharvest abiotic stresses as a tool for enhancing the nutraceutical content and adding-value of fresh fruits and vegetables. Journal of Food Science 68: 1560-1565.

Conesa R, Andreu S, Fernández PS, Esnoz A and Palop A. (2009). Nonisothermal heat resistance determinations with the thermoresistometer Mastia. Journal of Applied Microbiology 107: 506-513.

Deutsch JC. (2000). Dehydroascorbic acid. Journal of Chromatography A 881: 299-307.

Di Cagno R, Minervini G, Rizzello CG, De Angelis M and Gobbetti M. (2011). Effect of lactic acid fermentation on antioxidant, texture, colour and sensory properties of red and green smoothies. Food Microbiology 28: 1062-1071.

FAO/WHO (2004). Vitamin and Mineral Requirements in Human Nutrition, (2nd ed.). Geneva: World Health Organization.

FDA. CFR-Code of Federal Regulations Title 21, 2015. Available at: http:/www.accessdata.fda.gov/scripts/cdrh/ cfdocs/cfcfr/CFRSearch.cfm?fr=101.54 (accessed 12 May 15).

Fernández-León MF, Fernández-León AM, Lozano M, Ayuso MC, Amodio ML, Colelli G, et al. (2013). Retention of quality and functional values of broccoli 'Parthenon' stored in modified atmosphere packaging. Food Control 31: 302-313.

Geeraerd AH, Valdramidis VP and Van Impe JF. (2005). GInaFiT, a freeware tool to assess non-log-linear microbial survivor curves. International Journal of Food Microbiology 102: 95-105.

Hanschen FS, Lamy E, Schreiner M and Rohn S. (2014). Reactivity and stability of glucosinolates and their breakdown products in foods. Angewandte Chemie (International Ed. in English) 53: 11430-11450. 
Keenan DF, Brunton NP, Gormley TR, Butler F, Tiwari BK and Patras A. (2010). Effect of thermal and high hydrostatic pressure processing on antioxidant activity and colour of fruit smoothies. Innovative Food Science and Emerging Technologies 11: 551-556.

Lee SK and Kader AA. (2000). Preharvest and postharvest factors influencing vitamin $\mathrm{C}$ content of horticultural crops. Postharvest Biology Technology 20: 207-220.

Maeda E. (2013). The effects of green smoothie consumption on blood pressure and health-related quality of life: A randomized controlled trial. Portland State University, Dissertations and Theses, 974.

Martínez-Hernández GB, Artés-Hernández F, Colares-Souza F, Gómez P, García-Gómez P and Artés F. (2013). Innovative cooking techniques for improving the overall quality of a kailan-hybrid broccoli. Food Bioprocess and Technology 6: 2135-2149.

Martínez-Hernández GB, Gómez PA, Artés F and ArtésHernández F. (2015). Nutritional quality changes throughout shelf-life of fresh-cut kailan-hybrid and 'Parthenon' broccoli as affected by temperature and atmosphere composition. Food Science and Technology International 21: 14-23.

Martínez-Hernández GB, Gómez PA, Pradas I, Artés F and Artés-Hernández F. (2011). Moderate UV-C pretreatment as a quality enhancement tool in fresh-cut Bimi ${ }^{\circledR}$ broccoli. Postharvest Biology and Technology 62: 327-337.

Matusheski NV, Juvik JA and Jeffery EH. (2004). Heating decreases epithiospecifier protein activity and increases sulforaphane formation in broccoli. Phytochemistry 65: 1273-1281.

Meng X, Zhang M, Zhan Z and Adhikari B. (2014). Changes in quality characteristics of fresh-cut cucumbers as affected by pressurized argon treatment. Food and Bioprocess Technology 7: 693-701.

Munyaka AW, Makule EE, Oey I, van Loey A and Hendrickx M. (2010). Thermal stability of 1-ascorbic acid and ascorbic acid oxidase in broccoli (Brassica oleracea var. italica). Journal of Food Science 75: 336-340.

Ortega-Anta R, López-Sobaler A, Andrés-Carvajales P, Requejo-Marcos A, Aparicio-Vizuete A and MolineroCasares L. (2008). Programa Para Evaluación de Dietas y Gestión de Datos de Alimentación DIAL 1.0 ${ }^{\odot}$. Madrid, Spain: ALCE Ingeniería.

Prior RL, Wu X and Schaich K. (2005). Standardized methods for the determination of antioxidant capacity and phenolics in foods and dietary supplements. Journal of Agriculture and Food Chemistry 53: 4290-4302.

Rangkadilok N, Tomkins B, Nicolas ME, Premier RR, Bennett RN, Eagling DR, et al. (2002). The effect of post-harvest and packaging treatments on glucoraphanin concentration in broccoli (Brassica oleracea var. italica). Journal of Agricultural and Food Chemistry 50: 7386-7391.

Regulation EC 1441/2007. (2007). Commission regulation on microbiological criteria for foodstuffs. Official Journal of the European Union 322: 12-29.
Rodríguez-Verástegui LL, Martínez-Hernández GB, Castillejo N, Gómez PA, Artés F and Artés-Hernández F. (2015). Bioactive compounds and enzymatic activity of red vegetable smoothies during storage. Food and Bioprocess Technology 9: 137-146.

Van Eylen D, Oey I, Hendrickx M and Van Loey A. (2007). Kinetics of the stability of broccoli (Brassica oleracea $\mathrm{Cv}$. Italica) myrosinase and isothiocyanates in broccoli juice during pressure/temperature treatments. Journal of Agricultural and Food Chemistry 55: 2163-2170.

Verkerk R, Dekker M and Jongen WMF. (2001). Post-harvest increase of indolyl glucosinolates in response to chopping and storage of Brassica vegetables. Journal of the Science of Food and Agriculture 81: 953-958.

Verkerk R, Van der Gaag MS, Dekker M and Jongen WMF. (1997). Effects of processing conditions on glucosinolates in cruciferous vegetables. Cancer Letters 114: 193-194.

Vig AP, Rampal G, Thind TS and Arora S. (2009). Bio-protective effects of glucosinolates. A review. $L W T-$ Food Science and Technology 42: 1561-1572.

Walkling-Ribeiro M, Noci F, Cronin DA, Lyng JG and Morgan DJ. (2010). Shelf life and sensory attributes of a fruit smoothie-type beverage processed with moderate heat and pulsed electric fields. LWT-Food Science and Technology 43: 1067-1073.

Wang R, Wang T, Zheng Q, Hu X, Zhang Y and Liao X. (2012). Effects of high hydrostatic pressure on colour of spinach puree and related properties. Journal of the Science of Food and Agriculture 92: 1417-1423.

Wang R, Xu Q, Yao J, Zhang Y, Liao X, Hu X, et al. (2013). Post-effects of high hydrostatic pressure on green colour retention and related properties of spinach puree during storage. Innovative Food Science and Emerging Technologies 17: 63-71.

Wellburn AR. (1994). The spectral determination of chlorophylls a and b, as well as total carotenoids, using various solvents with spectrophotometers of different evolution. Journal of Plant Physiology 144: 307-313.

WHO/FAO. (2003). Population nutrient intake goals for preventing diet-related chronic diseases. In: Diet, Nutrition and the Prevention of Chronic Diseases. Geneva: WHO Technical Report Series, 916, p.95.

Wood FW and Goff TC. (1973). The determination of the effective shear rate in the Brabender viscograph and in other systems of complex geometry. Starch 25: 89-91.

Zapata S and Dufour JP. (1992). Ascorbic, dehydroascorbic and isoascorbic acid simultaneous determinations by reverse phase ion interaction HPLC. Journal of Food Science 57: 506-511.

Zhao L, Peralta-Videa JR, Rico CM, Hernandez-Viezcas JA, Sun Y, Niu G, et al. (2014). $\mathrm{CeO}_{2}$ and $\mathrm{ZnO}$ nanoparticles change the nutritional qualities of cucumber (Cucumis sativus). Journal of Agricultural and Food Chemistry 62: 2752-2759. 